\title{
TAX CONSEQUENCES OF LIMITATIONS UPON THE EXERCISE OF POWERS
}

\author{
Gharles L. B. Lowndes*
}

Limitations upon the exercise of powers over property may affect the disposition and use of the property subject to the power. The nature of any particular limitation may also carry with it a variety tax consequences under the federal income, estate, and gift taxes. The treatment of a limited power under these three taxes is often inconsistent and, on occasion, questionable.

\section{INTRODUCTION}

$T$ HERE ARE MANY situations where the existence of a power has important tax consequences under the federal income, estate, and gift taxes. Frequently, existence of a power is the occasion for imposing a tax. Less frequently, it will prevent imposition of a tax. To take a simple situation: Suppose that $A$ transfers property to $T$ in trust for $C$ and reserves power to revoke the trust. Retention of the power to revoke the trust keeps the trust property in $A$ 's taxable estate for purposes of the federal estate tax. ${ }^{1}$ It also makes the income from the trust taxable to $A$ under the income tax. ${ }^{2}$ But it prevents a complete transfer and a taxable gift under the gift tax. ${ }^{3}$

The situations where the existence of a power will attract or repel a tax are fairly well defined. However, the extent to which restrictions upon the exercise of a power will negative the existence of the power for tax purposes is much less certain. For example, in the hypothetical case in the preceding paragraph, suppose that $A$ 's power to revoke the trust was conditioned upon his surviving the trustee. Did $A$ make a taxable gift when he created the trust?

- A.B. 1923, Georgetown University; LL.B., 1926, S.J.D. 1931, Harvard University. James B. Duke Professor of Law, Duke University. Author [with Robert Kramer], Federal Estate and Gift TAXes (2d ed. 1962).

1 INT. REv. CODE of 1954, § 2038. Unless otherwise indicated, subsequent references to statutory provisions in the text and in the following footnotes are to the Internal Revenue Code of 1954, as amended.

2 INT. REv. CODE OF 1954, § 676 (a).

${ }^{3}$ See Lowndes \& Kramer, Federal Estate \& Gifr Taxes, § 28.1, at 613 (2d ed. 1962) [hereinafter cited as LowNDES \& KRAMER]. 
Is the income from the trust taxable to $A$ during $T$ 's life? If $A$ dies survived by $T$, must the trust property be included in his gross estate? The purpose of this article is to explore the tax effects of limitations upon the exercise of powers. Since there are various types of restrictions upon the exercise of powers, it is necessary to consider the tax effects of each type of limitation. As a preliminary step, it will be pertinent to look at the different kinds of limitations on the exercise of powers without attempting at this point to relate them to their tax consequences.

\section{Limtitations on the Exercise of Powers}

Perhaps the most obvious limitation upon the exercise of a power is physical conditions that make it impossible to exercise the power. For example, suppose that $A$, after creating a revocable trust, is cast away on a desert island where it is impossible for him to communicate with the trustees to revoke the trust.

Another fact which may prevent the exercise of a power is a lack of capacity on the part of the donee. Both lack of capacity and physical inability are extrinsic limitations on the exercise of the power, that is, limitations arising from circumstances existing independently of the power. In addition to extrinsic limitations on the exercise of a power, there may be intrinsic limitations, that is, restrictions which were written into the power and are a part of the power itself. Such intrinsic limitations include the requirement that the donee of the power must procure the co-operation of some other person to exercise the power. They also include conditions which must exist before the power can be exercised and requirements that the power must be exercised in a certain capacity, such as a provision that the owner of the power can exercise the power only so long as he acts as trustee of a specified trust.

There are a number of other possible limitations on powers which might conceivably be regarded as restrictions upon the exercise of a power, although they may also be classified as limitations upon the potential beneficiaries of the power or upon the purposes for which the power can be exercised. For example, a power may be limited with respect to the persons in whose favor it can be exercised. ${ }^{4}$ It is possible to regard this limitation as restricting the

\footnotetext{
"Consideration of the tax consequences of the distinction between "general" and "special" powers is beyond the scope of this discussion. It is interesting to note, however, a basic difference in the assumptions underlying the taxation of the two
} 
exercise of the power to the permissible beneficiaries under the power, although it is more convenient for present purposes to classify it as a limitation upon the persons who may benefit from the power-that is, as a limitation on the scope of the power, rather than upon its exercise. Again, the trustees of a trust may be given a power which is governed by an external standard, such as power to invade the corpus of the trust in behalf of the income beneficiary to the extent that this is necessary to maintain the beneficiary in his accustomed manner of living. It is possible to view the requirement

types of powers. Donated powers are not taxed unless the donee of the power possesses a "general" power, that is, power to appoint to himself or his estate which is tantamount to the beneficial ownership of the property subject to the power. The $\operatorname{tax}$ in this instance is premised upon substantial ownership of the property subject to the power. Thus, for example, property subject to a donated power is not taxed to the donee's estate under the estate tax ( $\$ 2041)$, nor included in his gross gifts under the gift $\operatorname{tax}(\S 2514)$, unless the donee can appoint the property to himself or his estate or what is regarded as the equivalent, his creditors or the creditors of his estate. The estate tax on reserved powers is predicated, however, upon retention of a degree of control which prevents the transfer from being complete until the transferor's death; it need not approach the level of beneficial ownership. Tlus, for example, property transferred by a decedent during his life must be included in his gross estate if he retained power to alter the beneficial enjoyment of the property, even though he could not recapture the property for himself, Porter v. Commissioner, 288 U.S. 436 (1933), and even though his power was restricted to a limited number of persons or merely involved accelerating the enjoyment of a single person. Lober v. United States, 346 U.S. 335 (1953); Struthers v. Kelm, 218 F.2d 810 ( 8 th Cir. 1955). A similar theory prevails under the gift tax, where a reserved power to alter enjoyment of property will prevent a complete transfer and a taxable gift, although the donor's power does not extend to making himself a beneficiary of the transfer. Estate of Sanford v. Commissioner, 308 U.S. 39 (1939). One situation where the distinction between reserved powers and donated powers seems to be ignored under the estate tax is in connection with the "incidents of ownership" which make life insurance taxable to the estate of the insured under $\S 2042$. Apparently, insurance will be taxed to the estate of an insured who did not purchase or transfer the insurance if he possessed incidents of ownership in the insurance at his death, although these incidents could not be exercised in his own favor. For example, if $W$ insured $F$ 's life and gave $H$ power to change the beneficiaries under the policy with the stipulation that $H$ could not make himself or his estate a beneficiary, the proceeds of the insurance would be taxable to $H^{\prime}$ 's estate under $\S 2042$.

The distinction between "general" and "special" powers which exists under the estate and gift taxes finds expression in $\S 678$ of the income tax. Section 678 taxes the income from a trust to a person who is not the grantor of the trust, if he is given power, exercisable alone, to vest the corpus or income of the trust in himself. A donated power to appoint the income from, or the corpus of, the trust to someone else does not make the income from the trust taxable to the donee of the power, because it cannot be equated with substantial ownership of the trust income. If, however, a person is given power, exercisable alone, to vest the income or corpus of the trust in himself, and he later releases or modifies this power, so that he can no longer acquire the income or corpus, he will still remain taxable upon the income from the trust, if the modified power would have subjected him to a tax under $\$ \S 673-77$, if he had been the grantor of the trust and the power a reserved power. 
that the trust property shall be invaded only to the extent necessary for the beneficiary's support as a limitation on the exercise of the power, although it appears more accurate to treat the definite standard as a limitation upon the purposes for which the power may be exercised. 5 Regardless of whether the present discussion is predicated upon a perfect classification, it will be confined to the limitations categorized above as restrictions upon the exercise of powers. If the enumeration is not exhaustive, it will probably prove exhausting.

\section{EXTRINSIC LIMITATIONS}

Apparently extrinsic limitations upon the exercise of a power do not negative the existence of the power for tax purposes. Before forming any firm conclusions on this point, it will be wise to examine separately the limitations imposed on the exercise of powers by physical conditions that make it impossible to exercise a power and the lack of legal capacity to exercise a power.

\section{Impossibility}

What little authority there is holds that physical conditions which prevent the exercise of a power do not negative the existence of the power for tax purposes. The leading case is Commissioner v. Estate of $\mathrm{Noel}_{\text {, }}^{6}$ where the Supreme Court held that the decedent possessed incidents of ownership in fiight insurance on his life wlich made the insurance taxable to his estate, even though at the time of his death in fiight it was physically impossible for him to exercise those incidents. Justice Black, speaking for a unanimous Court said:

Obviously, there was no practical opportunity for the decedent to assign the policies or change the beneficiary between the time he boarded the plane and the time he died. That time was too short and his wife had the policies in her possession at home. These circumstances disabled him for the moment from exercis-

5 Powers subject to a condition precedent and nondiscretionary powers governed by a definite external standard run into each other. At one end of the scale there are discretionary powers subject to a condition precedent, such as a power to revoke a trust if the grantor survives the trustee. At the other extreme, there are unconditional powers governed by a definite standard, such as a power to distribute to a beneficiary whatever income the beneficiary needs for his support and to accumulate the balance. In between there are conditional powers governed by an objective standard, such as a power to pay the medical expenses of a beneficiary if he becomes ill.

380 U.S. 678 (1965). 
ing those "incidents of ownership" over the policies which were undoubtedly his. Death intervened before this temporary disability was removed. But the same could be said about a man owning an ordinary life insurance policy who boarded the plane at the same time or for that matter about any man's exercise of ownership over his property while aboard an airplane in the three hours before a fatal crash. It would stretch the imagination to think that Congress intended to measure estate tax liability by an individual's fluctuating, day-by-day, hour-by-hour capacity to dispose of property which he owns. We hold that estate tax liability for policies "with respect to which the decedent possessed at his death any of the incidents of ownership" depends on a general, legal power to exercise ownership without regard to the owner's ability to exercise it at a particular moment. ${ }^{7}$

The physical conditions which prevent a person from exercising a power may take the form of various mental and physical disabilities. These types of physical impossibility blend into lack of legal capacity to act and must be considered in that context. There are several cases which have held that merely because the owner of a power was physically or mentally incapable of exercising it did not negative the existence of the power for tax purposes. ${ }^{8}$

Most of the cases in which it has been held that physical inability to exercise a power did not negative the existence of the power for tax purposes have involved the estate tax. Perhaps the closest analogy upon this point under the income tax may be found in the cases on constructive receipt holding that income is constructively received by a taxpayer who has an immediate and unimpeded right to the income, although he is physically unable to exercise the right. In Loose $v$. United States, ${ }^{9}$ for example, the Eighth Circuit held that a cash basis taxpayer constructively received interest represented by bond coupons when the coupons matured, even though they were in his safe deposit box and illness prevented him from going to the box and cutting the coupons. ${ }^{10}$

As far as semantics are concerned, it seems obvious that a power

IId. at 683-84. The Noel case was followed in United States v. Rhode Island Hosp. Trust Co., 355 F.2d 7 (Ist Cir. 1966).

${ }^{8}$ Hurd v. Commissioner, 160 F.2d 610 (1st Cir. 1947); Simons v. United States, 135 F. Supp. 461 (E.D.N.Y.), aff'd per curiam, 227 F.2d 168 (2d Cir. 1955), cert. denied, 350 U.S. 949 (1956); Estate of Virginia H. West, 9 T.C. 736 (1947), aff'd sub nom. St. Louis Union Trust Co. v. Commissioner, 173 F.2d 505 (8th Cir. 1949).

8 74 F.2d 147 (8th Cir. 1934).

${ }^{10}$ See McEuen v. Commissioner, 196 F.2d 127 (5th Cir. 1952); Charles F. Kahler, 18 T.C. 31 (1952). 
may be said to exist although it is temporarily impossible to exercise the power. Thus, the language of the statute imposing or excusing a tax upon the basis of "existence" of a power is fully compatible with attribution of tax consequences to a power where physical conditions preclude its exercise.

Apart from philosophical abstractions, it would appear that the crucial consideration which makes it imperative to treat a power as existing, even though it is physically impossible to exercise the power is the practical consequence of the opposite view. Mr. Justice Black put a judicial finger on the nub of the matter when he said "It would stretch the imagination to think that Congress intended to measure estate tax liability by an individual's fluctuating, day-byday, hour-by-hour capacity to dispose of property which he owns."11 Any such rule would not only entail inquiry into the circumstances surrounding the death of each individual decedent; it would tie in tax liability with the adventitious circumstances attending his death, rather than with the extent of his wealth and the property he controlled during his life. A man who is killed in an airplane crash might avoid having his life insurance and revocable trusts taxed to his estate, while another taxpayer expiring more sedately at home in bed would be taxed on these properties.

Testing the existence of a power by physical ability to exercise the power would create additional problems under the income tax. The estate tax is ordinarily imposed on the basis of conditions existing at the moment of the decedent's death. Consequently, if physical inability to exercise a power negatives the existence of the power for estate tax purposes, it would ordinarily be necessary only to see whether the decedent was able to exercise the power at the moment of his death. The income tax is imposed, however, upon the fiow of income over a taxable period. If inability to exercise a power negatived the existence of the power for purposes of the income tax, it would be necessary to determine the precise periods during which the inability persisted and to correlate these periods with the temporal flow of income whose taxation was called into question because of the existence of the power. ${ }^{12}$

\footnotetext{
11380 U.S. at $683-84$.

12 Of course, any doctrine that physical inability to exercise a power negatives the existence of the power for tax purposes would not be that simple. It would have to be refined by the development of all sorts of legal niceties. For example, there would be the threshold question of what degrees of physical obstruction to the
} 


\section{Incapacity}

For tax purposes the authorities treat a lack of legal capacity to exercise a power in the same way as a physical inability to exercise it. Some of the earlier Tax Court cases, which held that mental incompetence to exercise a power did not prevent taxing the power, intimated that a judicial declaration of incompetence might terminate a power for tax purposes. ${ }^{13}$ In Round $v$. Commissioner, ${ }^{14}$ however, the First Circuit held that trust property was taxable to the estate of the grantor where he reserved power to alter the trust, although at the time of his death he had become incompetent to manage his own affairs due to old age and a conservator had been appointed. Moreover, the final position of the Tax Court seems to be that a power will not cease to exist for tax purposes even where the owner of the power is judicially declared to be incompetent. ${ }^{15}$

Although the regulations do not contain any general statement to the effect that legal inability to exercise a power does not negative the existence of the power for tax purposes, this has been the posi-

exercise of a power amounted to physical inability to exercise the power. Moreover, since many decedents fall into a coma or period of unconscionsness before they die, it would be necessary to determine whether this type of inability to exercise a power negatived the existence of the power under the estate tax. Indeed it might even be requisite to explore the question of whether, when a person dies, there is a period after bodily activity has apparently ceased but before death actually occurs; and whether an inability to exercise a power during this interval would be fatal to a tax predicated upon the existence of the power. When the question of what amounts to inability to exercise a power is settled, it would be pertinent to consider the effect of voluntarily creating conditions which make it impossible to exercise a power. For example, if the owner of a power voluntarily takes an airplane flight making it impossible to exercise the power, would that entail different tax consequences than a disabling accident unwillingly thrust upon him which made it impossible for him to exercise the power? Of course, once the problem of voluntary and involuntary action was opened up, this would let in the subtler nuances of primary and secondary intention. Would it make any difference if inability to exercise a power was incurred for the specific purpose of escaping a tax in connection with the existence of the power? For example, would it affect the taxability of the income from a revocable trust to the grantor of the trust, if the grantor immured himself in the heart of the Amazonian jungle, where it was impossible for him to communicate with the trustee and exercise the power, either to study the primitive culture of the area, or with the primary objective of escaping a tax on the income from the trust? Admittedly, this seems to be far-fetched. But it is a sample of the kind of legal hair-splitting that would inevitably be encountered if one embraced the basic premise that the inability to exercise a power negatived the existence of the power for tax purposes.

${ }^{13}$ See, e.g., Estate of Edward L. Hurd, 6 T.C. 819, 823 (1946), aff'd, 160 F.2d 610 (1st Cir. 1947).

14 332 F.2d 590 (1st Cir. 1964).

15 See Estate of Charles S. Inman, 18 T.C. 522, 526-27 (1952), rev'd on other grounds, 203 F.2d 679 (2d Cir. 1953). 
tion of the Treasury in the specific instances in which it has committed itself. Section 2503 (c) of the 1954 Code provides that a gift to a minor qualifies for the annual exclusion if, in addition to meeting the other requirements of the section, ${ }^{18}$ the donated property must be paid to the minor's estate or to his appointees under a general power of appointment if he dies under twenty-one. According to the regulations, the statute will be satisfied if the infant donee is given a general power of appointment, although under the local law a minor lacks capacity to exercise a power of appointment. ${ }^{17}$ In Revenue Ruling 55-518 $8^{18}$ it was held that property subject to a general power of appointment was taxable to the estate of the donee even though she was incompetent to exercise the power. According to the ruling: "There is a distinction between the existence of a power and the capacity to exercise it. The taxable event is the possession at death of the power rather than an exercise of the power."10

Revenue Ruling 55-518 involved a fact situation where a husband died and left property in trust for his wife, giving her the right to the income from the property during her life and an unqualified power to invade the principal. The widow was mentally incompetent at all times from the date of the husband's death in 1950 until her own death in 1954. The ruling held that the wife's inability to exercise the power did not affect the existence of the power for tax purposes. Consequently, the property subject to the power was taxable to her estate and also qualified for the marital deduction in the husband's estate. In connection with the marital deduction, the ruling refers to Estate of Frank E. Tingley, ${ }^{20}$ which was affirmed under the name of Starrett $v$. Commissioner ${ }^{21}$ by the First Circuit. In Tingley, a man died leaving property in trust for his wife for life, with an unqualified power to invade the principal of the trust. The widow's right to demand the income from the trust and her power to invade the corpus of the trust were to cease "in case of her legal incapacity from any cause or upon the appointment of a guardian, conservator, or other custodian of her person

\footnotetext{
${ }^{18}$ The gift must also be expendable "by or for the benefit of the donee" during his minority. INT. REv. CODE OF 1954, $\$ 2503$ (c) (1).

${ }^{17}$ Treas. Reg. § 25.2503-4 (b) (1958).

18 1955-2 CuM. BULL. 384.

$10 I d$. at 385 .

2022 T.C. 402 (1954).

${ }^{31} 223$ F.2d 163 (1st Cir. 1955).
} 
or estate." 22 The Government argued that the trust did not qualify for the marital deduction because the widow's power to appoint the trust property to herself was not exercisable "in all events." The executor sought to rebut the Government's position by pointing out that the widow could not exercise any power if she became incapacitated. Consequently, the express limitations upon the exercise of her power merely echoed those implied by law and did not actually limit the exercise of the power. The Tax Court held that the trust did not qualify for the marital deduction and the judgment of the Tax Court was affirmed by the First Circuit. Judge Magruder said that the express limitations upon the exercise of the power went beyond those implied by law, because if the widow became incapacitated, her ability to exercise the power, apart from the express limitations on the exercise of the power, would merely be suspended, while under the terms of the trust her power was terminated entirely. ${ }^{23}$

Section 2038 (c) provides that the powers taxable under that section do not include a power to alter (but not revoke) a trust, whose relinquishment was not taxed as a gift under section 1000 (e) of the 1939 Code, provided the donee of the power was under a "mental disability" to relinquish the power for a continuous period beginning not less than three months before December 31, 1947, and ending with his death. ${ }^{24}$ Section 2038 (c) relates back to the relief provision written into the law after the Supreme Court decided in Estate of Sanford $v$. Commissioner ${ }^{25}$ that a transfer to a trust, under which the grantor reserved power to change the beneficiaries of the trust, although he could not make himself a beneficiary, was not a taxable gift. Out of consideration for grantors

\footnotetext{
22 Id. at 165 .

${ }^{23} \mathrm{As}$ far as the language of the statute is concerned, it would appear that a power may "exist" even though the owner of the power lacks legal capacity to exercise the power. There are several references in the 1954 Code to a "legal disability" or "mental disability" to release or relinquish a power, which do not appear particularly germane in the current context. Section 2041 (a) (1) of the estate tax provides that a power of appointment created before October 22, 1942, will not be taxed, if the power was reduced to a nontaxable power before November 1, 1951; or, in case the donee of the power was under a legal disability on October 21, 1942, within six months of the removal of the disability, if that is later than November 1, 1951. There is a similar provision under $\$ 2514$ (a) of the gift tax. Obviously neither of these provisions cast any light on the general problen of whether a lack of capacity to exercise a power negatives the existence of the power for tax purposes.

${ }^{2}$ See Int. Rev. Code of $1939, \S 1000$ (e), added by ch. $63, \S 502$ (a), 58 Stat. 71 (1944), as amended, ch. 143, $\S 2$ (a), 61 Stat. 178 (1947), as amended.

25308 U.S. 39 (1939).
} 
who had reported the creation of such trusts as taxable gifts, Congress provided by what eventually became section 1000 (e) of the 1939 Code, that in the case of such trusts created before 1939, the power to alter the trust could be relinquished without incurring a gift tax if this was done after January 1, 1940, but before January 1, 1948. The statute was later amended to provide that if the grantor of the trust was under a mental disability to relinquish the power to alter the trust for a period beginning not less than three months before December 31, 1947, and continuing until his death, the retention of the power should not incur the estate $\operatorname{tax}^{20}$ In 1959 this amendment was incorporated into the 1954 Code by section 2038 (c).27 It is doubtful if any generalization can fairly be drawn from section 2038 (c) about the effect of incapacity to exercise a power upon the existence of the power for tax purposes. $\mathrm{Ob}$ viously, however, since section 2038 (c) states that inability to exercise a power in the specific situation covered by that subsection prevents recognition of the power for tax purposes, any inference that could be drawn from this provision would be to the effect that inability to exercise a power does not generally negative the existence of the power for tax purposes.

From the viewpoint of sound tax policy, there are, to a greater or lesser degree, the same reasons for holding that legal incapacity does not prevent the existence of a power for tax purposes that there are for arguing that impossibility does not negative the existence of a power. Legal capacity to exercise a power does not fluctuate on the day-to-day, hour-to-hour basis that physical ability to exercise a power does. It would not be as difficult to prove that a taxpayer lacked capacity to exercise a power at a given moment as it might be to prove the absence of physical ability to exercise the power. Moreover, there might not be the same inequity in exempting a person who lacked capacity to exercise a power from a tax because of the power that there would be in exempting a person from a tax in connection with a power because of the temporary impossibility of exercising the power. On the other hand, a power

\footnotetext{
${ }^{28}$ Int. Rev. Code of 1939, $\S 811$ (d) (4), added by ch. 512, $\$ 208,67$ Stat. 623 (1953), as amended, ch. $63, \S 1,70$ Stat. 23 (1956).

${ }^{27}$ INT. REv. CODE OF 1954, $\S 2038$ (c). "As a result of this bill [\$ 2038 (c)], and previous actions, the exception for mentally incompetent would apply to all years from 1947 forward, so long as the decedent involved is mentally incompetent from October 1, 1947, to the date of his death." S. REP. No. 478, 86th Cong., 1st Sess. (1959). See Lowndes \& KRAMER $§$ 28.5.
} 
may be exercised by à guardian, a committee or a court for a person who lacks capacity to exercise the power himself, ${ }^{28}$ so it is hard to see any injustice in taxing the power, even though the donee may be personally incapable of exercising it.

It might be argued that a power of appointment, which the donee of the power lacks capacity to exercise, should not qualify property for the marital deduction under the estate or gift tax, or for the annual exclusion in the case of a gift to an infant, because the premise upon which the deduction or exclusion is granted is that the entire property qualifying for the deduction or exclusion passes to the donee spouse or infant without any strings. It is true that the incompetent wife who is given a power which she cannot exercise is not given very much. However, insofar as the power makes the property subject to the power taxable to her estate, ${ }^{29}$ it seems fair enough to hold that the power qualifies the property for the marital deduction. If the power did not qualify the property for the marital deduction, it would be impossible for a man whose wife was incompetent to take advantage of the deduction. As far as qualifying property for the annual exclusion is concerned, it is true that a power which cannot be exercised by an infant does not give the infant much control over the property subject to the power. However, it exposes the property to a tax in the infant's estate to the same extent as if he had received full ownership of the property. ${ }^{30}$ Inasmuch as the infant is treated as the absolute owner of the property subject to the power for the purpose of taxing it to his estate, it is difficult to see any injustice in treating the gift in the same way as far as the annual exclusion is concerned.

\section{INTRINSIC LIMITATIONS}

\section{Joint Powers}

One significant difference between extrinsic and intrinsic limitations upon the exercise of powers, from a tax point of view, is that the statute says little or nothing about the effects of extrinsic limita-

\footnotetext{
${ }^{28}$ E.g., City Bank Farmers Trust Co. v. McGowan, 323 U.S. 594, 598-99 (1945) (power exercised by court).

${ }^{20}$ Rev. Rul. 55-518, 1955-2 CUM. Bur.. 384.

${ }^{30}$ INT. REv. CODE OF 1954, § 2503 (c) (2) (B) specifies that the power of appointment given to the infant must be a taxable power under $\$ 2514$ (c) to qualify the gift for the annual exclusion. The regulations under $\$ 2503$ specifically provide that a disability to exercise the power by the donee-minor under local law does not disqualify the gift. Treas. Reg. § 25.2503-4(b) (1958).
} 
tions, which are left to the "common law" of taxation. On the other hand, it deals in some detail with certain aspects of intrinsic limitations. In the case of joint powers, or powers whose exercise is limited by the necessity of getting someone else to concur in the exercise of the power, the statutory background is quite detailed.

(a) Estate Tax

There is an interesting divergence between the way in which the income and estate taxes treat joint powers and powers exercisable by one other than a decedent or grantor. The estate tax imposes a tax on powers which were exercisable by the decedent alone, or by the decedent in conjunction with any other person. ${ }^{31}$ It does not, however, tax a decedent on property which he has transferred subject to a power to alter or revoke exercisable by one other than the decedent without the decedent's concurrence. ${ }^{82}$ As far as the income tax is concerned, the test of a revocable trust is whether power to alter or revoke the trust can be exercised without the concurrence of an adverse party. ${ }^{33}$ If it can, the income from

${ }^{31}$ INT. REv. CODE of 1954, $\S 2036$ (a) (2) taxes the right the decedent retained during his life (or the equivalent statutory period) to designate the enjoyment of property which he has previously transferred whether the right was exercisable by the decedent "either alone or in conjunction with any person . . . ." Section 2038 (a) (1) imposes a tax where, at the date of the decedent's death, the enjoyment of property which the decedent had previously transferred could be affected "through the exercise of a power . . . by the decedent alone or by the decedent in conjunction with any other person ... to alter, amend, revoke or terminate ...." Section 2042 (2) taxes life insurance payable to beneficiaries other than the estate of the insured to the insured's estate "with respect to which the decedent possessed at his death any of the incidents of ownership, exercisable either alone or in conjunction with any other person."

However, under $\S 204 \mathrm{I}$ (b) (1)(B), a general power to appoint the enjoyment of property not previously transferred by the decedent (and thus, not subject to $\S 2038$ ) which cannot be exercised by the donee without the concurrence of another person, is not taxable, if the power was created on or before October 21, 1942. Joint powers created after that date are taxable to the limited extent set forth in $\S 2041$ (b) (1)(C) (iii), unless the person required to concur in the exercise of the power is the donor of the power or a person having a substantial adverse interest in the property subject to the power, $\$ 2041$ (b) (l) (C).

${ }^{32}$ E.g., Commissioner v. Irving Trust Co., 147 F.2d 946 (2d Cir. 1945); Estate of Lester Hofheimer, 2 T.C. 773 (1943), af'd on this point, 149 F.2d 733 (2d Cir. 1945); cf. Anna B. Kneeland, 34 B.T.A. 816 (1936).

${ }^{33}$ INT. REv. CODE OF 1954, $\S 674$ taxes the income from a trust which can be altered without the consent of an adverse party to the grantor of the trust. Section 676 also taxes the income from a trust which can be revoked without the consent of an adverse party to the grantor. Income from a trust which may be distributed to, or accumulated for future distribution to, the grantor of the trust, without the concurrence of an adverse party, is taxed to the grantor under $\S 677$. Moreover, the exercise of certain administrative powers over trust property may make the income taxable to the grantor under $\S 675$, if the powers may be exercised without the 
the trust is taxable to the grantor of the trust even though the grantor is not required to participate in the exercise of the power.

According to the estate tax "any other person" means any other person, including a person possessing a substantial adverse interest in the property subject to a power. ${ }^{34}$ Consequently, a trust will be taxable to the grantor's estate if he retained power to alter or revoke the trust, even though the power could be exercised only with the concurrence of a beneficiary of the trust. ${ }^{35}$ This appears reasonable in view of the fact that when the decedent created the trust he was free to choose a complacent beneficiary, subservient to his will, with whom to exercise the power. Ownership of a substantial economic interest in property transferred by a decedent by the person who must concur in the exercise of a power to alter or revoke the transfer, is no real guaranty that the property has passed beyond the transferor's control, where the decedent was free to select the person whose concurrence is necessary to exercise the power. ${ }^{36}$ In this connection it is interesting to note that the only part of the estate tax where the fact that a person whose concurrence is required to exercise a power possesses a substantial adverse interest in the property subject to the power assumes any significance is the provision taxing joint powers of appointment. Joint powers created before October 22,1942 , are not taxed at all under the estate tax. ${ }^{37}$ The character of a person whose concurrence is required to exercise a pre-existing power is, therefore, immaterial. However, joint powers of appoint-

concurrence of an adverse party. Section 672 (a) defines an adverse party as "any person having a substantial beneficial interest in the trust which would be adversely affected by the exercise or nonexercise of the power which he possesses respecting the trust."

34 Helvering v. City Bank Farmers Trust Co., 296 U.S. 85 (1935).

B5 Ibid.

${ }^{80}$ The Supreme Court relied on this argument in upholding the constitutionality of a tax upon a trust that the grantor could revoke only with the consent of a beneficiary of the trust, when Mr. Justice Roberts said: "The respondent insists that a power to recall an absolute and complete gift only with the consent of the donee is in truth no power at all; that in such case the so-called exercise of the power is equivalent to a new gift from the donee to the donor. And so it is claimed that the statute arbitrarily declares that to exist which in fact and in law is nonexistent. The position is untenable. The purpose of Congress in adding clause (d) to the section as it stood in an earlier act was to prevent avoidance of the tax by the device of joining with the grantor in the exercise of the power of revocation someone whom he believed would comply with his wishes. Congress may well have thought that a beneficiary who was of the grantor's immediate family might be amenable to persuasion or induced to consent to a revocation in consideration of other expected benefits from the grantor's estate." Id. at 90 .

${ }^{37}$ INT. REv. CODE OF 1954, § 2041 (b) (1) (B). 
ment created after October 21, 1942, are taxable unless the person whose concurrence is required to exercise the power is the donor of the power, ${ }^{38}$ or a person possessing a substantial adverse interest in the property subject to the power. ${ }^{30}$ Presumably, the reason why donated powers of appointment, which are taxed under section 2041, are treated differently than reserved powers taxed under the other provisions of the estate tax, is that the donee of a joint power of appointment does not name the person whose concurrence is required to exercise the power of appointment. Therefore, the fact that the person who must concur in the exercise of the power of appointment has a substantial interest in the property subject to the power which may be prejudiced by the exercise of the power may actually limit the donee's control over the property subject to the power.

Although joint powers of appointment created after October 21, 1942, are taxed under the estate tax unless the person who must concur in the exercise of the power is the donor of the power or a person possessing a substantial adverse interest in the power, the tax on joint powers of appointment is strangely ambiguous. According to the statute, only a fraction of the property subject to the power, equal to the value of the property divided by the total number of possible appointees who must participate in the exercise of the power and the donee, is included in the donee's gross estate. ${ }^{40}$ Presumably, the fractional treatment rests upon the theory that the decedent's substantial ownership of the property was limited to the fraction taxed to his estate. It is interesting to notice that the fractional theory does not apply to the taxation of joint powers under other parts of the statute. Thus, for example, if the decedent during his life created a trust and retained power to revoke the trust with the consent of ten other persons, the entire trust property would be included in his gross estate, just as though he had retained power to revoke the trust alone. Apart from the unique way in which joint powers are treated under the provision taxing powers of appointment, there is the further problem of what happens to the other parts of the property subject to the power and not included in the donee's gross estate in the event the power is exercised. ${ }^{41}$

\footnotetext{
${ }^{38}$ INT. REv. CODE of 1954, § 2041 (b) (1) (C) (i).

${ }^{30}$ INT. REv. CoDE of 1954, $\S 2041$ (b) (1) (C) (ii).

${ }^{\circ}$ INT. REv. CODE OF 1954, $\$ 2041$ (b) (1) (C) (iii).

"1 Are these parts taxed to the persons required to concur in the exercise of the
} 
It seems sensible to tax property transferred by a decedent during his life under the estate tax where he retained a taxable power over the transferred property exercisable either alone or in conjunction with any other person, including a person possessing a substantial adverse interest in the transferred property. The principal defect in connection with the taxation of powers under the estate tax lies in the failure to tax inter vivos transfers by a decedent where the decedent gave a power to alter or revoke the transfer to someone else. Commentators generally agree that it does not make sense to tax a transfer which the transferor can alter or revoke only with the consent of a person possessing a substantial adverse interest in the transferred property, while permitting a transfer that can be altered or revoked by the trustee or some nonadverse person alone to go tax-free. ${ }^{42}$ There is no appreciable difference between a transfer in trust which can be revoked by the transferor with the consent of the trustee and a transfer which the trustee can revoke alone. Presumably, the transferor controls his own actions so in both cases the revocation of the transfer depends solely on the will of the trustee. Perhaps the most convincing illustration of the fallacy behind the rule exempting transfers that can be revoked by one other than the transferor from the estate tax is the suggestion that a transfer which can be altered or revoked by another person with the consent of the transferor is not taxable, because power to alter or revoke the transfer is vested in the other person and the transferor has simply a veto over his exercise of the power. ${ }^{43}$ Fortunately, this view probably does not represent the law. ${ }^{44}$ It seems obvious that there is not a shade of real difference between a trust which may be revoked by the settlor with the consent of the trustee and a trust revocable by the trustee with the consent of the settlor. Theoretically, where the trustee has power

power under the gift tax upon the theory that they made a taxable gift when they consented to the exercise of the power, or, if the donee died without exercising the power, on the theory that they made an inter vivos release of the power when it lapsed at the donee's death?

12 LOWNDES \& KRAMER $\$ 9.4$, at 166 .

${ }^{43}$ See Estate of Arnold Resch, 20 T.C. 171 (1953); Estate of Clayton W. Sherman, 9 T.C. 594 (1947); Orrin G. Wood, 40 B.T.A. 905 (1939) (gift tax).

"See Thorp's Estate v. Commissioner, 164 F.2d 966 (3d Gir. 1947), cert. denied, 333 U.S. 843 (1948); Du Charme's Estate v. Commissioner, 164 F.2d 959 (6th Cir. 1947); Goldstein's Estate v. United States, 122 F. Supp. 677 (Ct. Cl. 1954), cert. denied, 348 U.S. 942 (1955); Estate of Marion B. Gebbie, 23 P-H Tax Ct. Mem. 192 (1954); Lorraine M. G. Dresselhuys, 40 B.T.A. 30 (1939) (gift tax); Rev. Rul. 55-683, 1955-2 CuMr. Bull. 603. 
to revoke with the consent of the settlor, he must initiate the revocation of the trust. Practically, however, there is nothing to prevent the settlor from suggesting to the trustee that they revoke the trust. Ultimately, regardless of how the power to revoke the trust is phrased, revocation depends upon whether the grantor can persuade the trustee to agree to it.

The estate tax is on sound ground in taxing transfers to the estate of the transferor where he retained power to alter or revoke the transfer at his death, even though the power could only be exercised with the concurrence of a person possessing a substantial adverse interest in the transferred property. Since the decedent was free to select the person whose concurrence was necessary to exercise the power, limiting the tax to powers that could only be exercised by the decedent with the consent of a nonadverse party would allow transfers which could be altered or revoked with the consent of a subservient beneficiary to escape tax, even though the transferor had not really parted with control over the transferred property. The estate tax should be amended, however, to impose a tax where power to alter or revoke a transfer is vested in persons other than the transferor. Nor should this tax be limited to situations where the possessor of the power lacks a substantial adverse interest in the transferred property. If this limitation were written into the law, it would be inconsistent with the tax that is imposed where the decedent and a person possessing a substantial adverse interest in transferred property have power to alter or revoke the transfer. Moreover, it is possible for a person to retain control over transferred property even though he gives a person possessing a beneficial interest in the property power to alter or revoke the transfer, if he is careful to give this power to a donee who will comply with his wishes.

But if the estate tax were amended to provide that any transfer that can be altered or revoked by any person, or group of persons, should be taxed to the estate of the transferor, would this abolish tax? Any trust may be altered by the action of all of the beneficiaries, with the concurrence of the settlor if the alteration frustrates an essential purpose of the settlor in creating the trust and otherwise without his consent. ${ }^{45}$ To prevent irrevocable trusts from

45 SCOTt, TRUSTS $\S 338$, at 2477-78 (2d ed. 1956). 
being taxed to the settlor's estate, the statute might provide that trusts which could be altered or revoked by any person or persons other than all of those beneficially interested in the trust, should be taxed to the settlor's estate. This approach would be consistent with the Supreme Court's decision in Helvering v. Helmholz, ${ }^{46}$ which held that a trust revocable by the settlor only in conjunction with all of the beneficiaries of the trust was actually an irrevocable trust and therefore was not taxable to the settlor's estate under the present language of the statute which taxes a trust revocable by the grantor in conjunction "with any other person."

(b) Income $\operatorname{Tax}$

The income tax proceeds generally upon the premise that when property has passed beyond the control of the grantor of a trust, it is no longer desirable to tax the income from the trust to the grantor, and assumes that this occurs when the trust cannot be altered or revoked without the consent of a person possessing a substantial adverse interest in the trust, ${ }^{47}$ or according to the regulations, in the income whose taxation is in question. 48 If a trust can be altered or revoked without the concurrence of a person holding a substantial adverse interest, the income from the trust will be taxed to the grantor. It is not necessary that the power to alter or revoke the trust be vested in the grantor or that he must participate in the exercise of the power. In one respect the income tax lays down a more sensible rule for taxing revocable trusts than the estate tax, since trusts may be treated as revocable trusts under the income tax when they can be altered or revoked, even though the grantor's concurrence is not required. From another point of view, however, the income tax rule is less satisfactory than the estate tax, since, unlike the estate tax, a trust will not be treated as a revocable trust if the power to alter or revoke the trust cannot be exercised without the consent of an adverse party, who according to the income tax statute is "any person having a substantial beneficial interest in the trust which would be adversely affected by the exercise or nonexercise of the power which he possesses respecting the trust." "40 The defect in the income tax rule is that it conclusively

\footnotetext{
10296 U.S. 93 (1935). See Treas. Reg. § 20.2038-1 (a)(2) (1958); LowndEs \& KRAMIER $\$ 9.3$.

${ }^{17}$ See note 33 supra.

¿ Treas. Reg. § 1.672 (a)-1 (1956).

to INT. Rev. CoDe of 1954, § 672 (a).
} 
presumes that a beneficiary of a trust will necessarily act to protect his own interests rather than conform to the wishes of the grantor of the trust. Obviously, this ignores the fact that the grantor selects the beneficiary who is to exercise the power and he can vest it in his wife or child, or anyone else who might exercise the power as the grantor wishes. ${ }^{50}$

Apart from the abstract wisdom of the rule that a trust will be treated as irrevocable if it cannot be revoked without the concurrence of an adverse person, it is a difficult rule to apply in practice, because it is frequently hard to determine whether the person who has power to alter or revoke a trust has a substantial adverse interest in the trust in a specific situation. ${ }^{51}$ It would seem that the desirable way of taxing trusts under the income tax, as well as under the estate tax, would be to treat a trust as revocable as long as power to revoke the trusts is lodged in anyone other than all of the beneficiaries of the trust. It is difficult to see any reason for different rules under the two taxes. If it is proper to treat a trust which can only be revoked with the concurrence of a beneficiary of the trust as a revocable trust under the estate tax, because the grantor of the trust can select a complacent beneficiary to exercise the power, why should the same trust be treated differently under the income tax? Similarly, if a trust that can be altered or revoked without the participation of the grantor of the trust is treated as a revocable trust under the income tax, why should the same trust be treated differently under the estate tax?

Although section 674 provides that income from an inter vivos

\footnotetext{
${ }^{50}$ See note 36 supra. In Altmaier v. Commissioner, 116 F.2d 162 (6th Cir. 1940), the court taxed the income from a revocable trust to the grantor of the trust, although the grantor could only revoke with the consent of his wife, a heneficiary possessing a substantial interest in the trust. The court contended that the wife did not possess a substantial adverse interest because of the intimate family relation between her and the grantor of the trust. The other side of this same argument is illustrated by Judge Hastie's dissent in Latta v. Commissioner, 212 F.2d 164, 167 (3d Cir.), cert. denied, 348 U.S. 825 (1954), where he argued that a person whose interests were actually adverse to those of the grantor was a person possessing a substantial adverse interest in the trust, although he was not a beneficiary of the trust. The great majority of the cases, however, ignore the actual relation between the grantor of a trust and a person who must join with the grantor in exercising a power over the trust property. They regard a person as possessing a substantial adverse interest if he has a substantial beneficial interest that would be prejudiced by the exercise of the power. Latta v. Commissioner, supra; Camp v. Commissioner, 195 F.2d 999 (1st Cir. 1952); Commissioner v. Prouty, 115 F.2d 331 (1st Cir. 1940). This is the position adopted by the income tax statute. INT. REv. CODE OF 1954, § 672 (a).

${ }^{52}$ See LOWNDES \& KRAMER $§ 28.10$.
} 
trust shall be taxed to the grantor of the trust where the grantor or a nonadverse party, or both, have power to alter the beneficial enjoyment of the trust, the general rule is qualified by ten exceptions. ${ }^{62}$ That is, there are ten powers to affect enjoyment which will not make the income from a trust taxable to the grantor, even though they can be exercised without the concurrence of an adverse party. Eight of these excepted powers may be vested in anyone, including even the grantor of the trust. ${ }^{53}$ However, the power to sprinkle income or corpus freely among the beneficiaries of a trust will make the income from the trust taxable to the grantor of the trust where the power can be exercised without the concurrence of an adverse party, unless the power is vested in "independent trustees." 54 According to section 674 (c), "independent trustees" mean "a trustee or trustees, none of whom is the grantor, and no more than half of whom are related or subordinate parties who are subservient to the wishes of the grantor." A "related or subordinate party" is defined by section 672 (b) as

(1) the grantor's spouse if living with the grantor; (2) any one of the following: the grantor's father, mother, issue, brother or sister; an employee of the grantor; a corporation or any employee of a corporation in which the stock holdings of the grantor and the trust are significant from the viewpoint of voting control; a subordinate employee of a corporation in which the grantor is an executive.

Section 672 (c) goes on to provide that "a related or subordinate party shall be presumed to be subservient to the grantor in respect of the exercise or nonexercise of the powers conferred on him unless such party is shown not to be subservient by a preponderance of the evidence."

¿2 INT. REv. CODE OF 1954, \$674. Excepted from the operation of this section are the following: (1) a power to apply the income to the support of a dependent, (2) a power to affect the beneficial enjoyment only after expiration of a ten-year period, (3) certain powers exercisable only by will, (4) a power to allocate among charitable beneficiaries, (5) a power to accelerate distributions of corpus where there is no power to add new beneficiaries, (6) a power to withhold income temporarily under certain conditions, (7) a power to withhold income during the disability of a beneficiary, (8) a power to allocate receipts and disbursements between corpus and income, (9) a power to sprinkle income or corpus vested in independent trustees, and (10) a power to allocate income according to an ascertainable and reasonably definite external standard vested in a trustee other than the grantor or his spouse. See Note, 18 VAND. L. REv. 1899 (1965).

${ }^{63}$ INT. REv. CODE of 1954, $\$ 674(\mathrm{~b})$. These are the first eight powers listed in note 52 supra.

o. INT. REv. Code of 1954, § 674 (c). 
It is a little difficult to take section 674 (c) seriously. Although it provides that the income from a sprinkling trust is not taxable to the grantor of the trust, if the power to sprinkle income or corpus of the trust is vested in "independent trustees," the "independent trustees" need not be really independent at all. For example, a man could not create an inter vivos trust for his children and name his wife as trustee and give her discretion to sprinkle the income from the trust among the children, without being taxed upon the income from the trust. But he could create the trust and avoid having the income taxed to him if he made his wife and a trust company joint trustees and gave them power to sprinkle the income. Or if he did not like trust companies and wished to keep everything in the family, he could make his wife and his nephew trustees and give them power to sprinkle the trust income or corpus. In both cases the trustees would be independent according to the statutory definition, since one half of the trustees (the trust company in one case and the nephew in the other) would not be related or subordinate parties. It may be proper to recognize an exception to the general rule that income from a trust whose beneficial enjoyment can be altered without the concurrence of an adverse party is taxable to the grantor of the trust in the case of sprinkling trusts. It is difficult to see why this exception should not be made candidly by providing simply that a power to sprinkle income or corpus from a trust to any beneficiary except the grantor shall not make the income from the trust taxable to the grantor. It is hard to see any sensible reason for limiting the sprinkling trust exception to a trust where the power to sprinkle is vested in trustees who are called independent trustees but obviously are not. The needless (because it is useless as far as promoting any discernible policy is concerned) complexity of the sprinkling trust exception to section 674 (a) is illustrated by the requirement that the sprinkling power must be vested in trustees "no more than half of whom are related or subordinate parties who are subservient to the wishes of the grantor." According to section 672 (d), the fact that a person is related or subordinate to the grantor does not establish conclusively that he is also subservient to the grantor. In fact, section 672 (c) says that it may be proved that he is not subservient to the grantor by a preponderance of the evidence. Actually, therefore, in the hypo-

\footnotetext{
v Ibid.
} 
thetical situation above, the grantor of the sprinkling trust could make his wife the sole trustee of the trust and give her power to sprinkle the income and corpus of the trust, without making the income taxable to himself, if he could prove that she was a very obdurate lady who had no respect for his wishes. Of course, no one would create a sprinkling trust where the sole trustee, or more than half of the co-trustees, were related or subordinate parties, and rely on proof of lack of subservience to prevent the income from the trust being taxed to the grantor. The rebuttable presumption of subservience is a further example of statutory filigree that complicates the law without serving any useful purpose.

Section 674 (d) provides that the income from a trust shall not be taxed to the grantor of the trust because of a power to allocate income among the beneficiaries of the trust according to a "reasonably definite external standard," as long as this power is lodged in "a trustee or trustees, none of whom is the grantor or spouse living with the grantor." Again, it is difficult to see the policy behind this fine distinction. According to section 674 (c), a man could create a trust under which the trustees of the trust were given unlimited power to sprinkle the income among the beneficiaries and make his wife and a trust company trustees, without becoming liable for a tax upon the income from the trust. The grantor would not be immune from taxation on the trust income under section 674 (d), even though the exercise of the power was limited by a definite external standard, since despite the fact that the trustees were "independent," the grantor's spouse was one of the trustees. Obviously, section 674 (d), as the regulations point out,, ${ }^{56}$ affords an additional exception to the general rule laid down by section 674 (a). Taken in conjunction, however, the two sections indicate how fine the statutory distinctions are and how insulated from notions of policy. Why should income from a trust under which the trustee is given power to allocate the income from the trust among the beneficiaries of the trust according to a definite standard, be taxed to the grantor, if the trustee is his wife, but not if the trustee is his son or daughter? Do the distinctions laid down in sections 674 (c) and 674 (d) promote any useful policy beyond affording counsel an opportunity to show how deft he is in drafting around the basic statutory precept taxing the income from a trust to a gxantor

\footnotetext{
Treas. Reg. \& 1.674 (d)-1 (1956).
} 
who has retained power to control the beneficial enjoyment of the trust property?

It is difficult for the skeptical observer to repress the feeling that the scholarly distinctions set forth in the statute with respect to related or subordinate parties and independent trustees are merely window dressing to conceal what the statute really does. If it is desirable to exclude sprinkling trusts from trusts whose income is taxable to the grantor of the trust, why not do so candidly? Why not adopt a simple statute that says that power to sprinkle the income or corpus of a trust among the beneficiaries of the trust, excluding the grantor, will not render the income from the trust taxable to the grantor? This, after all, is what the statute does.

One way to elucidate the tissue-paper-thin statutory distinctions involving related or subordinate parties and independent trustees is to take a specific situation. Suppose that $H$ wishes to create an inter vivos trust of one million dollars for his wife, $W$, and their three children, $A, B$, and $C$, and further wishes to retain power to allocate the income and principal among the beneficiaries as he sees fit. As a practical matter he can do this by vesting power to sprinkle the income and corpus of the trust in the trustees and making himself, his wife, or a certain trust company, or any combination of the three, the trustee or trustees, since his wife and the trust company will follow his wishes. Apart from tax considerations, therefore, it does not matter whether $H$ names himself or his wife or the trust company, or any combination of the three, as trustee or trustees. But look at the tax differences.

If $H$ names himself sole trustee, he will not incur a gift tax when he creates the trust. But the trust property will be taxable to his estate, and the income from the trust will be taxed to him. If $H$ names himself and the trust company as co-trustees, the tax results will be the same as if he had appointed himself sole trustee. $H$ will not incur a gift tax when he creates the trust; the trust property will be taxable to his estate; and he will be taxed upon the income from the trust.

If $H$ names himself and his wife as co-trustees, the tax consequences will depend primarily upon whether $W$ has a substantial adverse interest in the trust. Presumably she lacks such an interest because whatever she derives from the trust will depend upon what 
$H$ chooses to give her. ${ }^{57}$ On the assumption that $W$ lacks a substantial adverse interest, $H$ will not be held to have made a taxable gift when he created the trust. The income from the trust will be taxed to $H$, since, even though it can be shown that $W$, a related party, is not subordinate to her husband, the trust does not fall under the exception for sprinkling trusts set forth in section 674 (c) if the grantor is one of the trustees. ${ }^{58}$ Regardless of whether or not $W$ has a substantial adverse interest in the trust, the trust property is taxable to $H$ 's estate under the estate tax..$^{59}$

If $H$ designates himself, his wife, and the trust company co-trustees of the trust, the tax results will be the same as if he were to make himself and his wife co-trustees. Assuming that $W$ lacks a substantial adverse interest in the trust property, $H$ will not be held to have made a taxable gift when he creates the trust. However, the income from the trust will be taxed to $H$, and the trust property will be included in his gross estate at his death. ${ }^{80}$

If $H$ makes $W$ the sole trustee, he will make a taxable gift at the time he creates the trust, but the trust property will not be taxed to his estate under the estate tax, unless the transfer to $W$ was in contemplation of death. ${ }^{81}$ The trust property will be taxable to $W$ 's estate at her death because of her power. to appoint the trust property to herself. ${ }^{62}$ Apparently, the income from the trust will also be taxable to $W$ under section $678(\mathrm{a})$. Section $678(\mathrm{~b})$ provides that "subsection (a) shall not apply with respect to a power over income, as originally granted or thereafter modified, if the grantor of the trust is otherwise treated as the owner under sections 671 to 677 inclusive." Although at first glance it might appear that section $678(\mathrm{~b})$ would control in this situation and that the income from the trust would be taxed to the grantor $H$, rather than to $W$ despite her power to withdraw income or corpus, section $678(\mathrm{~b})$

"Tee Fulham v. Commissioner, 110 F.2d 916 (1st Cir. 1940).

${ }^{68}$ The income from the trust is not taxable to $W$ under $\S 678$ (a) because of her power to call for the income and principal of the trust, since this power is not exercisable by $W$ alone.

60 Nor will the trust property be taxed to W's estate at her death under $\$ 2041$ since she can only exercise her power with the concurrence of the donor.

${ }^{00}$ The income from the trust will not be taxed to $W$ either because $H$ is taxed or because she did not have the power to call for income and corpus on her own. Nor will the trust property be taxable to her estate since her power to appoint the trust property could only be exercised with the concurrence of the donor.

o1 See Herzog v. Commissioner, 116 F.2d 591 (2d Cir. 1941); cases cited note 32 supra.

${ }^{02}$ INT. REv. CoDE of 1954, § 2041. 
only taxes income to the grantor when sections 671 to 677 so provide. In the hypothetical case, $W$ appears to have a substantial adverse interest in the trust because of her sole power to withdraw the income or corpus of the trust. ${ }^{63}$ Because there is no basis under section 678 (b) for taxing the income of the trust to the grantor under the grantor trust provisions, the income from the trust is taxable to $W$ under section 678 (a). It might be assumed from the failure of section 678 (b) to mention a power over principal, that a power to demand corpus will make the income from a trust taxable to the person possessing this power in preference to the grantor, although the income from the trust would otherwise be taxable to the grantor under sections 671 to 677 . Regardless of whether or not this is true, it seems clear that the income from the trust will be taxable to $W$ in the hypothetical case under section 678 (a) because $W$ has a substantial adverse interest (because of her power to withdraw income and principal) sufficient to relieve the grantor of tax liability under sections 671 to $677 .^{64}$

If $H$ makes the trust company and $W$ co-trustees of the trust, he will make a taxable gift at the time he creates the trust, and the trust property will not be taxed to his estate at his death under the estate tax, unless the trust was created in contemplation of death. ${ }^{65}$ When $W$ dies, the trust property will be taxed to her estate under section 2041. Presumably, the full value of the trust property will be taxed to W's estate, because although she could only exercise her power to withdraw the trust principal with the concurrence of the trust company, the trust company would not be a possible appointee under the power. The income from the trust will not be taxed to $W$ under section 678 (a), however, because her power over the income and corpus of the trust is not exercisable solely by herself. Nor will the income of the trust be taxed to $H$, because the power to sprinkle is vested in independent trustees, since even though $W$ is a related party who is presumably subservient to the grantor, the trust company is not.

The fine distinctions surrounding sprinkling trusts afford an op-

${ }^{83}$ Section 672 (a), after specifying that an adverse party is one having a substantial beneficial interest in the trust, adds: "A person having a general power of appointment over the trust property shall be deemed to have a beneficial interest in the trust."

${ }^{64}$ See Treas. Reg. $\$ 1.678$ (a)-1 (1956).

${ }^{\circ 5}$ See cases cited notes 32,61 supra. 
portunity for the skillful lawyer to parade his talents, as he threads his way through the complexities of the statute to achieve the most desirable tax consequences for his client. These gossamer distinctions are also tax traps for the guileless grantor whose counsel lacks the same familiarity with the statutory niceties. Do the statutory minutiae reflect any worthwhile tax policies or are they simply a means of creating lucrative employment for tax lawyers?

(c) Gift Tax

The gift tax lacks explicit provisions about the tax effects of powers, or limitations on the exercise of powers, except for section 2514, which deals with the taxation of powers of appointment. Section 2514 follows the estate tax. Powers of appointment are divided into powers created on or before October 21, 1942, and powers created after that date. Joint pre-existing powers are not taxed. ${ }^{66}$ Joint powers created after October 21, 1942, are taxable unless the donee can exercise the power only with the consent of the donor of the power ${ }^{67}$ or of a person possessing a substantial adverse interest in the property subject to the power. ${ }^{68}$ In the case of a taxable joint post- 42 power, only a fraction of the appointive property equal to the value of the property divided by a number made up of the sum of the donee of the power and the possible appointees who must concur in the exercise of the power is included in the donee's gross gifts when he exercises or releases the power. ${ }^{69}$ There is the same problem under the gift tax that exists under the estate tax as to what happens to the other parts of the appointive property that are not taxed to the donee. Are they taxed to the other co-holders of the power on the theory that they too made taxable gifts of their fractional shares of the appointive property when they concurred in the exercise or release of the power?

Transfers revocable by the transferor alone or by the transferor in conjunction with a person lacking a substantial adverse interest in the transferred property, are treated as incomplete transfers that are not subject to the gift tax. ${ }^{70}$ The 1932 Act originally provided explicitly that transfers of this kind were not taxable as gifts. ${ }^{71}$

\footnotetext{
OO INT. REv. CODE OF 1954, § 2514 (c) (2).

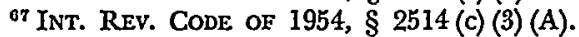

${ }^{O S}$ INT. Rev. CODE OF 1954, \& 2514 (c) (3) (B).

${ }^{\circ}$ INT. REv. CODE OF 1954, § 2514 (c) (3) (C).

${ }^{70}$ Treas. Reg. § 25.2511-2 (e) (1958).

${ }^{71}$ Revenue Act of 1932, ch. 209, §501 (c), 47 Stat. 245.
} 
After the Supreme Court reached the same conclusion under the 1924 Act in the absence of any explicit provision on the point, ${ }^{72}$ Congress deleted the language of the 1932 Act expressly exempting transfers revocable by the transferor without the concurrence of an adverse party. ${ }^{73}$ The committee report was careful to note, however, that this was done because the provision was surplusage after the Supreme Court's decision in Burnet v. Guggenheim, ${ }^{74}$ and did not change the law. ${ }^{70}$

A transfer that can be revoked by the transferor only with the concurrence of a person possessing a substantial adverse interest in the transferred property is a complete transfer and a taxable gift. ${ }^{70}$ This is contrary to the estate tax concept of a complete transfer. Under the estate tax, of course, any transfer which can be revoked by the transferor is an incomplete and taxable transfer, regardless of the necessity of concurrence by an adverse party. ${ }^{77}$ According to the Supreme Court's reasoning in Smith v. Shaughnessy, ${ }^{78}$ however, a transfer is complete for gift tax purposes when the transferred property passes beyond the control of the transferor, regardless of how the transfer is treated under the estate tax. ${ }^{70}$ Pursuant to this premise the lower courts have held that a transfer that can be revoked only with the consent of a person possessing a substantial adverse interest in the transferred property is a complete transfer and a taxable gift, regardless of any inconsistency with the estate tax. 80

Apparently, however, the taxable gift in the case of a transfer that can be altered or revoked only with the consent of an adverse person, is limited to that part of the transferred property whose enjoyment cannot be altered or revoked without the consent of a

${ }^{72}$ Burnet v. Guggenheim, 288 U.S. 280 (1933).

${ }^{73}$ Revenue Act of 1934 , ch. $277, \S 511,48$ Stat. 758 .

74288 U.S. 280 (1933).

${ }^{75}$ H.R. REP. No. 704, 73d Cong., 2d Sess. 40 (1934); S. REP. No. 558, 73d Cong., 2d Sess. 50 (1934). Cf. Treas. Reg $\$ \S 25.2511-2$ (c), (e) (1958).

${ }^{76}$ Camp v. Commissioner, 195 F.2d 999 (lst Cir. 1952); Commissioner v. Prouty, 115 F.2d 331 (Ist Cir. 1940). See Latta v. Commissioner, 212 F.2d 164 (3d Cir.), cert. denied, 348 U.S. 825 (1954).

77 Helvering v. City Bank Farmers Trust Co., 296 U.S. 85 (1935).

78318 U.S. 176, 181 (1943).

${ }^{79}$ Although the Supreme Court intimated in Estate of Sanford v. Commissioner, 308 U.S. 39 , 45 (1939), that the test of a complete transfer under the gift tax was whether the transfer was treated as complete so that it escaped the estate tax, the Court abandoned this position in Smith v. Shaughnessy, supra note 78.

${ }^{80}$ See cases cited note 76 supra. 
person having an interest in that portion of the property. ${ }^{81}$ For example, if $A$ transferred property to $T$ in trust for $B$ for life, remainder to $C$ in fee and retained power to revoke the trust in whole or in part with the consent of $C$, he would make a taxable gift of $C$ 's remainder, but not of $B$ 's life estate. If $A$ retained power to revoke the trust only in its entirety with the consent of $C$, however, he would apparently make a gift of the entire property because this power could not be exercised without the consent of a person possessing a substantial adverse interest that would be affected by the exercise of the power. ${ }^{82}$

Presumably a substantial adverse interest means the same thing under the gift tax that it does under the income tax with one possible exception. There will apparently be a taxable gift of any interest, regardless of the substantiality of the interest, where the owner of the interest is required to concur in the exercise of a power affecting that interest, provided that the interest is susceptible of valuation. ${ }^{83}$ For example, suppose that $A$ transfers one million dollars to $T$ in trust to pay one hundred dollars of trust income to $B$ annually and to accumulate the balance of the income until $B$ 's death when the trust property and any accumulated income will be distributed to $C$ or his estate. $A$ reserves power to revoke the trust, but only in its entirety, with $B$ 's consent. Despite the fact that $A$ 's power to revoke the trust is limited to a power to revoke the trust in its entirety, so that any exercise of this power will necessarily affect $B$ 's interest in the trust, it seems clear that $A$ has not made a taxable gift of the entire trust property, because $B$ lacks a substantial adverse interest in the trust. It would appear, however, that there would be a gift of $B$ 's interest in the income of the trust, since there seems to be a complete transfer of this part of the trust property.

There is some uncertainty about how a transfer that can be altered or revoked by one other than the transferor, without the

\footnotetext{
${ }^{81}$ Camp v. Commissioner, 195 F.2d 999, 1004-05 (1st Cir. 1952).

${ }^{82}$ Id. at 1004 .

${ }^{83}$ Ibid. Judge Magruder said: "If the trust instrument gives a designated beneficiary any interest in the corpus of the trust property or of the income therefrom, which is capable of monetary valuation, and the donor reserves no power to withdraw that interest, in whole or in part, except with the consent of such designated beneficiary, then the gift of that particular interest will be deemed to be complete, for the purposes of the gift tax."
} 
transferor's concurrence, should be treated under the gift tax. ${ }^{84}$ Inasmuch as transfers of this type are not taxed under the estate tax, they should be taxed under the gift tax. Although the estate and gift taxes are not mutually exclusive, in the sense that a transfer taxable under one tax may not be taxed under the other, it is fairly obvious that Congress intended that they should be mutually inclusive. ${ }^{85}$ That is, Congress intended that a transfer which escaped the estate tax should be taxed under the gift tax. The cases appear to be tending toward a position where a transfer under which the transferee has uncontrolled discretion to return the transferred property to the transferor will be regarded as a complete transfer and a taxable gift. ${ }^{86}$ If, however, the transferor retains some equitable interest in the transferred property under which he might compel the transferee to return an indefinite part of the property to him, the transfer is incomplete and does not constitute a taxable gift. ${ }^{87}$ For example, if $A$ transferred property to $T$ in trust for $B$ for life, remainder to $C$ in fee, and gave $T$ complete discretion to amend the trust in any way he saw fit, the possibility that $T$ might pay over the trnst property to $A$ (provided that he is under no legal obligation to distribute the property to $A$ 's creditors) ${ }^{88}$ would not prevent the transfer to the trustee from being complete and taxable under the gift tax. If, however, T's power to alter the enjoyment of the

\footnotetext{
${ }^{84}$ See Lowndes, Some Doubts About the Use of Trusts to Avoid the Estate Tax, 47 MinN. L. REv. 31, 48-51 (1962).

${ }^{85}$ See H.R. REP. No. 708, 72d Cong,, 1st Sess. 28 (1932); S. REP. No. 665, 72d Cong., lst Sess. 40 (1932). See also Lowndes \& KRAMrer, $§$ 22.1-.2; Harriss, Legislative History of Federal Gift Taxation, 18 TAxes 531, 533 (1940).

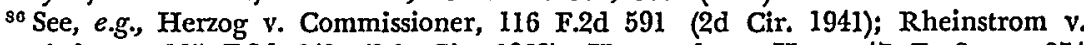
Commissioner, 105 F.2d 642 (8th Cir. 1939); Hernstadt v. Hoey, 47 F. Supp. 874 (S.D.N.Y. 1942); Minnie E. Deal, 29 T.C. 730 (1958); Treas. Reg. $\$ 25.2511-2$ (b) (1958). See also Miller, Minimizing Gift Taxes Through Use of Discretionary Powers, 1964 So. CAL. TAX INST. 547.

${ }^{87}$ E.g., Estate of Leon Holtz, 38 T.G. 37 (1962); Sarah Gilkey Vander Weele, 27 T.C. 340 (1956), aff'd, 254 F.2d 895 (6th Cir. 1958); Estate of Christianna K. Gramm, 17 T.C. 1063 (1951); Rev. Rul. 62-13, 1962-1 CuM. Bull. 181. If part of the property which may be returned to the donor can be ascertained definitely, then there will be a gift except for this amount. For example, in Daisy B. Plummer, 2 T.C. 263 (1943), the creator of a trust retained the income from the trust and a power to call for principal up to $\$ 15,000$ a year. The court held that she had made a taxable gift of the value of the trust property less the value of her life interest and $\$ 15,000$ a year principal multiplied by her life expectancy.

${ }^{88}$ Where under the local law the creditors of the grantor of a trust, under which the trustee had discretion to pay over the trust property to the grantor, could compel the trustee to pay them the trust property, the Tax Court held that the grantor possessed power to revoke the trust by incurring debts and did not make a taxable gift when he created the trust. Alice Spaulding Paolozzi, 23 T.C. 182 (1954).
} 
trust were limited to pay over whatever $T$ deemed necessary for $A$ 's support, it has been held that the transfer to $T$ is not a taxable gift, because $A$ retained an interest in the trust property. ${ }^{80}$ The difficulty with this position is that it seems to conflict with Robinette v. Helvering. ${ }^{90}$ In Robinette the Supreme Court held that a transferor's retention of some interest in transferred property would not prevent a taxable gift of the entire property, if it were impossible to value the retained interest. ${ }^{01}$ Conceding that $A$ retained an interest in the trust, because under appropriate circumstances an equity court would require the trustee to support $A$ from the trust, it seems obvious that $A$ 's interest cannot be valued. Moreover, if the transfer to the trust is not taxed as a gift, it will apparently escape both the gift and estate taxes. Since the power to apply the trust property for the support of the grantor is vested in one other than the grantor, it is not taxable under sections 2038 or 2036 (a) (2), which tax powers to affect the enjoyment of transferred property only where the power is vested in the transferor alone, or the transferor and some other person. Conceivably, it might be possible to regard the power as vested in the grantor because he could compel the trustee to pay over what is needed for his support. However, the power from this point of view is a power whose exercise is limited by an external standard or a nondiscretionary power which is not taxable under sections 2036 or $2038 . .^{22}$ At one time, this kind of transfer might have been taxed under the estate tax as a transfer

\footnotetext{
${ }^{80}$ Estate of Leon Holtz, 38 T.C. 37 (1962).

${ }^{\circ 0} 318$ U.S. 184 (1943).

01 If the donor's retained interest can be valued it will be subtracted from the amount of the gift. Thus, in Smith v. Shaughnessy, 318 U.S. 176 (1943), a man transferred property to his wife for life, remainder to the grantor if he survived his wife, and remainder to the wife's testamentary appointees, or intestate successors in default of appointment, if she survived him. The court held that the donor's reversionary interest should be subtracted from the amount of the gift, since it could be valued on the basis of the life expectancies of the husband and wife. But in Robinette $v$. Helvering, where the reversionary interest was dependent upon failure of issue and incapable of valuation, the Court held that nothing should be subtracted from the trust property in determining the annount of the taxable gift. Rev. Rul. 62-13, 1962-1 Cum. BuLl. 181, in which the Service acquiesced in Sarah Gilkey Vander Weele, 27 T.C. 340 (1956), aff'd, 254 F.2d 895 (6th Cir. 1958), attempts, with dubious success, to distinguish Robinette from the decisions holding that there is no taxable gift.

${ }^{03}$ See Jennings v. Smith, 161 F.2d 74 (2d Cir. 1947); Estate of Robert W. Weir, 17 T.C. 409 (1951); Estate of C. Dudley Wilson, 13 T.C. 869 (1949), aff'd, 187 F.2d 145 (3d Cir. 1951); Estate of Milton J. Budlong, 7 T.C. 756 (1946), aff'd in part, rev'd in part sub nom. Industrial Trust Co. v. Commissioner, 165 F.2d 142 (1st Cir. 1947).
} 
taking effect at death..$^{93}$ However, it is doubtful whether it is taxable under section 2037 in its present form. Section 2037 taxes a transfer as a transfer taking effect at death, where the possession or enjoyment of the transferee is dependent upon surviving the transferor and the transferor retained a reversionary interest in the transferred property which immediately before his death was worth more than five per cent of the value of the property. The trust in the hypothetical case meets the survivorship requirement for a transfer taking effect at death because the enjoyment of the beneficiaries of the trust is dependent upon T's failure to apply the trust property to $A$ 's support during his life. Moreover, the right to have the property applied for his support would qualify as a reversionary interest or a possibility that the trust property might return to $A$. However, it is doubtful whether this reversionary interest can meet the five per cent requirement. It seems to be the law that a reversionary interest will not meet the five per cent requirement where the taxpayer proves that immediately before the decedent's death the reversionary interest was worth less than five per cent of the value of the transferred property, or where, as would be the case here, he proves that the reversionary interest cannot be valued.94

The gift tax has no independent significance. It is designed as a supplement primarily to the estate tax and secondarily to the income tax to catch transfers made for the purpose of avoiding those taxes. ${ }^{95}$ In an ideal tax system, the gift tax would be correlated with the taxes it is intended to supplement. A transfer would be treated as a complete transfer and a taxable gift when the transfer was regarded as complete under the estate tax, that is, when the property transferred was no longer taxable as part of the transferor's gross estate, and the income from the property was no longer taxable to the transferor. Since the income and estate taxes have inconsistent tests of a complete transfer, it is obviously impossible to reconcile the gift tax with both the income and the estate taxes. Perhaps this is the reason the Supreme Court abandoned any attempt to align the gift tax with the estate and income taxes in

${ }^{93}$ Toeller's Estate v. Commissioner, 165 F.2d 665 (7th Cir. 1948); Bankers Trust Co. v. Higgins, $136 \mathrm{~F} .2 \mathrm{~d} 477$ (2d Cir. 1943); Blunt v. Kelley, 131 F.2d 632 (3d Cir. 1942).

Q4 See Estate of Frank W. Thacher, 20 T.C. 474 (1953); Lowndes \& KrAMER \$ 7.7, at $114-15$.

${ }^{\text {os }}$ See note 85 supra. 
Smith v. Shaughnessy, ${ }^{96}$ where the Court ruled that the test of a complete transfer for gift tax purposes is whether the transferred property has passed beyond the control of the transferor, rather than the way in which the transfer is treated under the income or estate taxes. ${ }^{97}$

If the definitions of a revocable trust under the income and estate taxes were rewritten to apply to any transfer where there is a power to alter or revoke the enjoyment of the trust property exercisable by anyone short of all those beneficially interested in the trust, it would be simple enough to define an irrevocable or complete transfer under the gift tax as a transfer where no one, other than all those beneficially interested, is given power to alter or amend the transfer.

\section{Contingent Powers}

(a) Estate Tax

The exercise of a power may be limited by a contingency which must occur before the power can be exercised. The estate tax has something to say about contingent powers, although not very much. Section 2038 imposes a tax where a decedent transferred property during his life and possessed power at the date of his death to alter, amend, revoke or terminate the enjoyment of the transferred property. Section 2041 taxes powers of appointment where the decedent had a taxable power of appointment at the date of his death. In the case of both sections, the statute provides that the power "shall be considered to exist on the date of the decedent's death," even though the exercise of the power was subject to a precedent giving of notice, or could take effect only on the expiration of a stated period after the exercise of the power, and the notice had not been given nor the power exercised before the decedent's death. ${ }^{98}$ There is one difference between section 2038 (b) and section 2041 (a) (2). Under section 2038 (b), which deals with revocable trusts, any interest which the decedent could not have recovered if he had given the prescribed notice or exercised the power during his life will be excluded from the gross estate. For example, if $A$ transferred property to a trust, which he retained power to revoke by giving one year's notice to the trustee, and died without giving the notice, the

\footnotetext{
${ }^{00} 318$ U.S. 176 (1943).

${ }^{\circ 7} \mathrm{Id}$. at 181.

${ }^{08}$ INT. REv. CODE OF 1954, $§ \S 2038$ (b), 2041 (a) (2).
} 
value of the trust property less the value of one year's enjoyment would be included in $A$ 's gross estate. There is no similar qualification under section 2041 (a) (2), which deals with powers of appointment. If $A$ had a taxable power of appointment, which he could exercise only upon giving one year's notice, and he died without giving the notice, presumably the full value of the property subject to the power of appointment would be included in his gross estate.

For many years the Treasury contended that contingencies in addition to those explicitly referred to by the statute did not prevent a power from being in existence and taxable. ${ }^{99}$ After the courts rejected this contention repeatedly, ${ }^{100}$ the Government modified its position. The regulations under the 1954 Code provide that a power to alter or revoke the enjoyment of transferred property will not be in existence at the transferor's death and will not be taxed under section 2038, if the exercise of the power is subject to a contingency which has not occurred at the transferor's death. ${ }^{101}$ The regulations take a similar position with respect to a power of appointment under section 2041.102 A power of appointment will not be in existence at the donee's death, so as to be taxable under section 2041, if the exercise of the power is subject to a condition which has not happened at the donee's death. In their zeal to make sure that contingent powers escape a tax under sections 2038 and 2041, the regulations under both sections provide that the powers of a trustee, which are normally attributed to a decedent who possessed power to remove the trustee and appoint himself trustee, will not be attributed to the decedent, if the power to remove the trustee was subject to a contingency that had not occurred at the decedent's death. ${ }^{103}$ For example, if $A$ transferred property to $T$ in trust for $C$ and gave $T$ power to revoke the trust, the trust property would be taxable to $A$ 's estate, if $A$ retained an unconditional power to remove the trustee and appoint himself trustee in his place. But if

${ }^{90}$ Treas. Reg. 105, $\$ 81.20$ (b) (3) (1952).

${ }^{100}$ E.g., Jennings v. Smith, 161 F.2d 74 (2d Cir. 1947); Helvering v. Tetzlaff, 141 F.2d 8 (8th Cir. 1944); Commissioner v. Flanders, 111 F.2d 117 (2d Cir. 1940); Day v. Commissioner, 92 F.2d 179 (3d Cir. 1937); Tait v. Safe Deposit \& Trust Co., 74 F.2d 851 (4th Cir. 1935); Winchell v. United States, 180 F. Supp. 710 (S.D. Cal. 1960), aff'd, 289 F.2d 212 (9th Cir. 1961); Estate of Frederick M. Kasch, 30 T.C. 102 (1958); Estate of Cyrus C. Yawkey, 12 T.C. 1164 (1949); Daisy C. Patterson, 36 B.T.A. 407 (1937), appeal dismissed, 99 F.2d 1007 (10th Cir. 1938).

101 Treas. Reg. § 20.2038-1 (b) (1958).

${ }_{102}$ Treas. Reg. $\$ 20.2041-3$ (b) (1958).

${ }^{103}$ Treas. Reg. $\S \S 20.2038-1$ (a) (3), .2041-1 (b) (1958). 
$A$ could only exercise this power after $T$ 's death and he predeceased $T$, the trust property would not be taxable to $A$ 's estate under section 2038 , according to the regulations.

It is easy to be misled by the regulations into thinking that the Treasury has retreated further in the taxation of contingent powers than it actually has. Although the regulations say that a contingent power is not taxable under section 2038, this concession is qualified by the observation that the power may be taxable under section 2036 (a) (2).104 Inasmuch as most transfers that are taxable under section 2038 are also taxable under section 2036 (a) (2), this is an important qualification. For example, suppose that $A$ transferred property to $T$ in trust to pay the income to $B$ for life, remainder to $C$ in fee, and provided that if $A$ outlived $B$, he should have power to revoke the trust. According to the regulations, if $A$ predeceased $B$, the trust property will not be taxed to his estate under section 2038, but it will be taxed under section 2036 (a) (2). Furthermore, if immediately before his death $A$ 's chance of outliving $B$ was better than one in twenty, $C$ 's remainder will also be taxable to $A$ 's estate under section 2037.

It is possible that the courts may refuse to uphold the Treasury's contention that contingent powers are taxable under section 2036 (a) (2). Most of the cases which held that a contingent power was not taxable under the 1939 Code involved the 1939 Code equivalent of section 2038.105 There were cases, however, which held that a contingent power was not taxable under the predecessors of both sections 2038 and 2036 (a) (2). ${ }^{108}$ Only one case seems to have suggested that a contingent power might be taxed under the 1939 Code equivalent of section 2036 (a) (2) although it was not taxable under $2038 . .^{107}$

There are two possible grounds for treating a contingent power differently under sections 2038 and 2036 (a) (2). Section 2038 (b) expressly provides that notice or lapse of time before a power can be exercised, or the exercise of the power takes effect, will not prevent a power from being in existence for the purpose of incurring

\footnotetext{
${ }^{204}$ Treas. Reg. $\$ 20.2038-1$ (b) (1958). See also Treas. Reg. $\$ 20.2036-1$ (b) (3) (1958).

${ }^{205}$ All of the cases cited in note 100 supra involved the pre-1954 Code equivalent of $\S 2038$, although some also considered the pre-1954 version of $\S 2036$ (a) (2).

${ }^{100}$ Jennings v. Smith, 161 F.2d 74 (2d Gir. 1947); Estate of Frederick M. Kasch, 30 T.C. 102 (1958).

${ }^{107}$ Estate of Cyrus C. Yarkey, 12 T.C. 1164 (1949).
} 
a tax under section 2038. It is possible to argue that by specifying that certain contingencies do not prevent the existence of a power, section 2038 (b) implies that other contingencies do, and, therefore, a power subject to some other contingency is not a taxable power under section 2038. There is no parallel implication about the fatal effect of contingencies under section 2036 (a) (2), because section 2036 does not specify any conditions that will not negative the existence of a power. Of course, this argument carries as much weight as one chooses to attribute to it. It is possible to argue that by providing expressly that notice and lapse of time do not negative the existence of a power, section $2038(\mathrm{~b})$ implies that other contingencies have this effect. It is just as easy, and perhaps more realistic, to say that by providing that the contingencies set forth in section 2038 (b) do not negative the existence of a power, Congress intended merely to make sure that these conditions would not prevent a tax under section 2038, without undertaking to deal with the effect of other contingencies.

Section 2038 imposes a tax only where a power to alter or revoke the enjoyment of transferred property was in existence at the transferor's death or released in contemplation of his death. In terms at least, section 2036 (a) (2) does not tax the existence of a power to designate the income or enjoyment of transferred property at the transferor's death, but taxes the transfer of property with retention of such a power for the transferor's life or the equivalent statutory period. ${ }^{108}$ Although it is conceivable that a distinction between the taxation of contingent powers under the two sections might be based upon this difference in statutory language, the distinction would be exceedingly tenuous. Despite the phrasing of section 2036 (a) (2), a transfer does not seem taxable under that section unless the power to designate the enjoyment of the property persists until the transferor's death. ${ }^{100}$ If the tax under section 2036 (a) (2) is actually predicated upon the existence of power to desiguate the enjoyment of the transferred property at the decedent's death, the failure of section 2036 to specify this requirement explicitly seems immaterial.

Even if the courts refuse to uphold the regulations and decide

\footnotetext{
${ }^{108}$ In addition to taxing the power reserved for life, $\S 2036$ (a) taxes powers retained "for any period not ascertainable without reference to his death or for any period which does not in fact end before his death ...."

${ }^{100}$ See Lowndes \& KrAMER $\$ 8.8$, at 135-36.
} 
that contingent powers are not taxable under section 2036 (a) (2), great care must be observed in employing contingent powers to avoid a tax under section 2037. Section 2037 defines a reversionary interest to include not only the possibility that property transferred by a decedent during his life may return to him or his estate, but also the possibility that the transferred property may become subject to a power of disposition by the decedent. ${ }^{110}$ A reversionary interest, therefore, includes a contingent power retained by a transferor to revoke the transfer or alter the enjoyment of the transferred property. Consequently, a contingent power will attract a tax under section 2037 if the other requirements for a transfer taking effect at death set forth in section 2037 are met. To come back to the hypothetical case posed earlier, suppose that $A$ transferred property to $T$ in trust for $B$ for life, remainder to $C$ in fee, and retained power to revoke the trust if he outlived $B$. If immediately before his death $A$ had a better than one in twenty chance of surviving $B$, the transfer meets the requirements of a transfer taking effect at death taxable under section 2037. In order to enjoy the property $C$ must outlive $A$. If $A$ outlives $B$, the trust property becomes subject to his power to dispose of the property. This is a reversionary interest, and since $A$ 's chance of outliving $B$ immediately before his death was better than one in twenty, the value of his reversionary interest exceeds five per cent of the value of the transferred property.

(b) Income Tax

There are a number of sections under the income tax where the existence of a power has important tax consequences. Before passing to the tax effects of limitations on the exercise of powers under the income tax, it will be helpful to consider the situations where the existence of a power may make the income from a trust taxable to one other than the trustee or beneficiary of the trust.

Income from a trust is taxable to the grantor of the trust where the grantor is regarded as the owner of the trust property producing the income because there is a power exercisable by the grantor or a nonadverse party, or both, without the approval or consent of any adverse party: (1) To alter the beneficial enjoyment of the trust property; ${ }^{111}$ (2) To exercise certain administrative powers; ${ }^{112}$

\footnotetext{
${ }^{210}$ INT. REv. CODE OF 1954, § 2037 (b) (2).

${ }^{111}$ INr. REv. CoDE of 1954, § 674 (a).

${ }^{112}$ INT. REv. CODE OF 1954, § 675 (4).
} 
(3) To revest title to the trust property in the grantor; ${ }^{113}$ (4) To distribute income from the trust to the grantor or accumulate income for future distribution to the grantor. ${ }^{114}$

In addition, the trust income may be taxed to a person, other than the grantor, who is regarded as the owner of the trust property because he has a power exercisable solely by himself to vest the corpus or the income of the trust in himself or who had such a power and reduced it to a power which would cause the income from a trust to be taxed to the grantor of the trust.115

The statute sheds a little light on the effect of conditions limiting the exercise of powers on the taxation of trusts. Section 672 (d) provides:

A person shall be considered to have a power described in this subpart even though the exercise of the power is subject to a precedent giving of notice or takes effect only on the expiration of a certain period after the exercise of the power.

This provision parallels the similar provisions found in section 2038 (b) and section 2041 (a) (2) of the estate tax. It might be possible to infer under the rule of inclusio unius est exclusio alterius that by providing explicitly that conditioning a power by requiring notice or a lapse of time does not prevent the existence of a power for income tax purposes, the statute implies that any other contingencies will negative the power under the income tax. Any such argument, however, would have to take account of other provisions of the statute which specify that certain conditional powers are not treated as taxable powers under the income tax. These powers are connected with section 673 and can be understood only in reference to that section. Under section 673 , the income from a trust will be taxed to the grantor of the trust, if the trust property will, or may reasonably be expected to, return to the grantor within ten years from the creation of the trust. In other words, under section 673 , income from a short-term trust is taxable to the grantor of the trust and a short-term trust is defined as a trust that will last for less than ten years, or, in the case of a trust of uncertain duration, may reasonably be expected to terminate within ten years. Under section $673(\mathrm{~b})$, the ten-year period is reduced to two years in the case

\footnotetext{
${ }^{113}$ INT. REv. CoDE of $1954, \S 676$ (a).

114 INT. REv. CoDE of 1954, \$ 677 (a).

${ }^{216}$ INT. REv. CODE OF 1954, § 678 (a).
} 
of a trust for certain kinds of charities, that is, income from a trust for a charity which is to last for at least two years will not be taxed to the grantor of the trust. Section 673 (c) introduces a final qualification to the ten-year rule by providing that a trust which will last at least for the life of the income beneficiary (even though his life expectancy is less than ten years) will not be taxed to the grantor of the trust. It seemed to the draftsmen of the 1954 Code that it would be inconsistent with section 673 to provide that income should be taxed to the grantor of a trust because of a power to affect the enjoyment of the trust that could not be exercised for a period which would not attract a tax under section 673. That is, it would be silly to provide that a power to revoke a trust would make the trust income taxable to the grantor of the trust, even though the power could not be exercised for ten years, when the fact that the trust property would automatically revert to the grantor of the trust at the end of ten years would not make the income of the trust taxable to the grantor. Consequently, section 674 (b) (2) provides that a power to alter beneficial enjoyment of a trust will not make the income from the trust taxable to the grantor of the trust, if the power cannot be exercised for ten years or for a period which would prevent the income from a short-term trust from being taxed to the grantor of the trust. Section $676(\mathrm{~b})$ lays down a similar exception for powers to revoke a trust that cannot be exercised for ten years, and the same provision appears in section 677 (a) with respect to a power to distribute income to the grantor of a trust or to accumulate income for future distribution to the grantor. It might be argued that by stating that certain conditions will prevent a power from being taxable, these provisions imply that other conditions will not prevent powers from being taxable. This position appears valid as far as limitations on the time when a power may be exercised are concerned. It is a fair inference from the provision that a power to revoke a trust which cannot be exercised for ten years from the creation of the trust does not make the trust income taxable to the grantor, that a power exercisable within ten years from the creation of the trust will make trust income taxable to the grantor. In the case of a revocable trust, the trust income might be taxable to the grantor, apart from section 676 (dealing with revocable trusts), under section 673, which taxes trust income to the grantor where the trust property may reason- 
ably be expected to revert to the grantor in ten years. If the power were merely a power to alter the trust which could not be exercised in favor of the grantor, this would preclude a tax under section 673. If, however, the power could be exercised within ten years of the creation of the trust, it should make the income from the trust taxable to the grantor of the trust under section 674. This follows not only as a negative inference from the statutory provision that a power to alter enjoyment of a trust that cannot be exercised for ten years from the creation of the trust does not make the income from the trust taxable to the grantor, but also from the further statement that if the power is still outstanding after the expiration of the period which prevents taxing income to the grantor, the income from the trust will be taxable to the grantor. This provision indicates that the grantor is sheltered from the income tax only as long as the exercise of a power to alter the trust is proscribed for a sufficient period to prevent the income from a shortterm trust from being taxed to the grantor under section 673 .

It seems obvious that the statutory provisions declaring that powers which can be exercised only after the expiration of a period which would prevent income from a short-term trust from being taxed to the grantor carry only the implication that powers whose exercise is proscribed for a shorter period are taxable powers. The sole purpose of these provisions is to reconcile the other sections of the statute with section 673, taxing the income from short-term trusts. They have no general implications concerning the taxability of contingent powers under the income tax.

The law is somewhat uncertain with respect to the income tax consequences of powers involving contingencies other than those explicitly covered by the statute. Most of the cases were decided under the 1939 Code and involved section $166,{ }^{116}$ which taxed the income from a revocable trust to the grantor of the trust, or section 167,117 which taxed income that could be distributed to, or accumulated for future distribution to, the grantor of the trust. It was fairly well settled under the 1939 Code that a contingent power to revoke a trust did not make income from the trust taxable to the grantor of the trust provided that the contingency was not some-

${ }^{116}$ Int. Rev. Code of 1939, $\S 166,53$ Stat. 68.

${ }^{117}$ Int. Rev. Code of $1939, \S 167,53$ Stat. 68, as amended, ch. 68, $\S 134,58$ Stat. 51 (1944). 
thing within the grantor's control.118 Some of the cases, however, leaned heavily on the language of the 1939 Code which taxed income from a trust to the grantor of the trust where power to revoke the trust was "vested" in the grantor. They reasoned that a contingent power did not make the income from the trust taxable to the grantor because the power was contingent and not "vested" in the grantor. ${ }^{119}$ Other cases were decided on the broader ground that a power subject to a contingency, which had not occurred, was not in existence, and did not, therefore, make income taxable to the grantor of a trust. ${ }^{120}$ It is perhaps important to notice that under the 1954 Code a power need not be "vested" in the grantor to make income from a trust taxable to the grantor, as far as the language of the statute is concerned. It is enough if the power is "exercisable" by the grantor or a nonadverse party. This would, of course, be a possible method of distinguishing the cases under the 1939 Code which held that a contingent power did not make income taxable to the grantor of a trust, if a court wished to distinguish them in dealing with contingent powers under the 1954 Code.

There is another point which should be kept in mind in applying the cases under the 1939 Code to the 1954 Code. Many of the cases involving contingent powers under the 1939 Code were cases where the contingency upon which it became possible for the grantor to exercise the power was the grantor's survival of the income beneficiary of the trust. Regardless of how contingent powers are treated generally under the 1954 Code, it is clear that power to revoke or alter a trust which the grantor can exercise only if he survives the income beneficiary of the trust will not make the trust income taxable to the grantor. Income from a trust is not taxed to the grantor of a trust, because the trust property will revert to the grantor at the income beneficiary's death under section 673 . Therefore, a power to alter or revoke a trust that cannot be exercised until

\footnotetext{
${ }^{118}$ E.g., Chertoff v. Commissioner, 160 F.2d 691 (6th Cir. 1947); Commissioner v. Betts, 123 F.2d 534 (7th Cir. 1941); Commissioner v. O'Keeffe, 118 F.2d 639 (Ist Cir. 1941); Corning v. Commissioner, 104 F.2d 329 (6th Cir. 1939); Commissioner v. Stokes, 79 F.2d 256 (3d Cir. 1935).

${ }^{110}$ E.g., Commissioner v. Betts, supra note 118, at 538-39; Commissioner v. O'Keeffe, supra note 118, at 642. See Helvering v. Dunning, 118 F.2d 341, 343 (4th Cir. 1941).

Int. Rev. Code of $1939, \S 166,53$ Stat 68 , provided that the trust income would be taxable to the grantor "where at any time the power to revest in the grantor title to any part of the corpus of the trust is vested" in the grantor, a nonadverse party, or the grantor in conjunction with a nonadverse party.

${ }^{220}$ E.g., Corning v. Commissioner, 104 F.2d 329 (6th Cir. 1939).
} 
after the death of the income beneficiary is not a taxable power under sections 674 (b) (2) and $676(\mathrm{~b})$.

Even though the fact that a power is contingent may prevent taxing the income from a trust to the grantor of the trust under sections 674 or 676 , it may not have that effect under section 677 . In Altmaier v. Commissioner, ${ }^{121}$ for example, $H$ transferred property to $T$ in trust to accumulate the income from the property until $H$ or his wife, $W$, died, whichever happened first. If $H$ predeceased $W$, the income from the trust was to be paid to $W$ during the remainder of her life, and if $W$ predeceased $H$, the income from the trust was to be paid to $H$ during the remainder of his life. After the death of the survivor of $H$ and $W$, there were remainders over. $H$ retained a joint power to revoke the trust with the concurrence of $W$ as long as $W$ lived, and a sole power to revoke the trust if he survived $W$. The court held that the income from the trust, which was accumulated, was taxable to $H$ under section 167 , the 1939 Code equivalent of section 677, because the trustee had power to accumulate income which might be held for future distribution to the grantor of the trust, $H$. The accumulated income might be distributed to $H$ because if $H$ survived $W$, he had sole power to revoke the trust and acquire the accumulated income. Income is taxable to the grantor of a trust if the income "may be" accumulated for future distribution. It is not necessary that the accumulated income must be distributed to the grantor. It is enough if the grantor has a chance to acquire it. The fact that his right to accumulated income is contingent does not prevent taxing the income to the grantor under section 677 , although there is some argument about the effect of a very remote contingency. According to most of the cases ${ }^{122}$ (although there may be a different view), ${ }^{123}$ if the grantor's chance of getting the accumulated income is so remote as to be unlikely to happen, the income from trust will not be taxed to him.

121 II6 F. 2d 162, (6th Cir. 1940).

${ }^{122}$ E.g., Frederick Ayer, 45 B.T.A. 146 (1941); Henry Martyn Baker, 43 B.T.A. 1029 (1941); Marrs McLean, 4I B.T.A. 565 (1940); Christopher I. Ward, 40 B.T.A. 225 (1939), rev'd on other grounds, 119 F.2d 207 (3d Cir. 1941); Genevieve F. Moore, 39 B.T.A. 808 (1939); William E. Boeing, 37 B.T.A. 178 (1938), rev'd on other grounds, 106 F.2d 305 (9th Cir.), cert. denied, 308 U.S. 619 (1939).

${ }_{123}$ "We think the statute means that if under any circumstances or contingencies any part of the accumulated income might inure to the benefit of the grantor such portion of the income is taxable to him." Kaplan v. Commissioner, 66 F.2d 401, 402 (Ist Cir. 1939). See also Treas. Reg. $\$ 1.677$ (a)-1 (c) (1956). 
Although there may be disagreement as to whether a remote chance of acquiring accumulated income will justify taxing the income to the grantor, there appears to be complete accord that the mere fact that a grantor's right to accumulated income is contingent does not prevent a tax. Therefore, the fact that the grantor in the Altmaier case ${ }^{124}$ had to outlive his wife to revoke the trust and get the accumulated income did not prevent the income from the trust from being taxed to him.

It is perhaps worth noting that there may be a possible distinction between a contingent right to accumulated income and a contingent power to accumulate income. It is possible that a contingent power to accumulate income for future distribution to the grantor will not make the income from the trust taxable to the grantor, although if there had been an unconditional power to accumulate income to which the grantor had only a contingent right, the income would have been taxed to him. For example, suppose that a man transfers property to a trustee to pay the income from the trust to the grantor's divorced wife for thirty years unless she remarries. If the wife remarries, the trustee is to pay her only one half of the income for the remainder of the thirty-year period and accumulate the balance. At the end of thirty years the trustee is to distribute the trust property and any accumulated income to the grantor or his estate. It is quite possible that none of the income from this trust may be taxable to the grantor of the trust as long as the wife does not remarry, if one takes the view that a contingent power is not in existence as long as the contingency has not happened and concludes therefrom that the trustee did not have a power to accumulate the trust income. Contrast this situation with a trust where the trustee is directed to pay over half of the income from a trust to the grantor's divorced wife for thirty years and accumulate the balance, and at the end of thirty years, if the wife has not remarried, to pay the accumulated income to her, but if she has remarried, to pay it to the grantor. In this case one half of the income from the trust would appear taxable to the grantor of the trust, regardless of whether or not the wife remarries. The power to accumulate income was not contingent. The only contingency involved was with respect to the grantor's right to accumulated income.

${ }^{124}$ See note 121 supra and accompanying text. 
Section 678, which taxes the income from a trust to a person other than the grantor of a trust because he possesses power to call for the income or corpus of the trust, is a provision which first appeared in the 1954 Code, although it was foreshadowed by the "Clifford Regulations"125 and the decisions under the 1939 Code. ${ }^{126}$ Although there do not appear to be any decisions with respect to the effect of a contingency limiting the power of the substantial owner of the trust property to call for the income or corpus of the trust under section 678, presumably contingencies will have the same effect here that is attributed to them in connection with grantor trusts. If a contingency will prevent income from a trust from being taxed to the grantor of the trust, it should have the same effect in the case of one other than the grantor who is regarded as the beneficial owner of the trust under section 678 .

\section{(c) Gift Tax}

Unlike the income and estate taxes where a power to alter or revoke a transfer will make the transferor liable for a tax, a power to alter or revoke a transfer prevents the gift tax from attaching to the transfer. Although there is not much authority as to the effect of a contingency upon a power to alter or revoke a transfer under the gift tax, it is generally assumed that a contingency limiting the exercise of the power will not prevent a complete transfer and a taxable gift unless the contingency is an event within the transferor's control.127 This follows from the position the Supreme Court took in Smith v. Shaughnessy, ${ }^{128}$ where it held that the test

${ }^{125}$ In Helvering v. Glifford, 309 U.S. 331 (1940), where a man declared himself trustee of property for his wife for five years, the Supreme Court held that he was taxable upon the income from the trust as the substantial owner of the fund. The Court did not attempt to tax the income to the grantor under $\$ 166$ of the 1939 Code as a revocable trust, but imposed the tax under $\S 22(\mathrm{a})$, the general statutory definition of gross income. The courts experienced so much difficulty in applying Helvering $v$. Clifford in subsequent cases that the Treasury issued the "Clifford Regulations," Treas. Reg. 118, $\$ 22$ (a)-21 to -22 (1949), in which it attempted to specify with some particularity the situations to which that case applied. The Clifford Regulations adopted the cases noted in note 126 infra, which applied the doctrine of substantial ownership of the clifford case to tax income from a trust to one other than the grantor of the trust when this other person could call for the income or corpus of the trust.

${ }^{128}$ Spies v. United States, 180 F.2d 336 (8th Cir. 1950); Bunting v. Commissioner, 164 F.2d 443 (6th Cir. 1947); Emery v. Commissioner, 156 F.2d 728 (1st Cir. 1946); Mallinckrodt v. Nunan, 146 F.2d 1 (8th Cir. 1945). See Funk v. Commissioner, 185 F.2d 127 (3d Cir. 1950).

${ }_{127}$ Rev. Rul. 54-537, 1954-2 CuM. Burt. 316.

${ }^{128} 318$ U.S. 176 (1943). 
of a complete transfer and a taxable gift is passage of the transferred property beyond the control of the transferor.

Even though a contingent power will not prevent a taxable gift if the contingency involves an event beyond the transferor's control, it may affect the amount of the gift. Thus, for example, if $A$ transfers property to $T$ in trust to pay the income from the property to $B$ for life, remainder to $C$ in fee and retains power to revoke the trust if he outlives $B$, the power to revoke the trust will not prevent a taxable gift, since surviving $B$ is something beyond $A$ 's control. The possibility that $A$ may outlive $B$ and regain control of the trust property, however, is a reversionary interest which $A$ retained in the property, the value of which must be subtracted from the amount of the gift, since it is susceptible to valuation by recognized actuarial techniques. ${ }^{128}$ If the limitation on $A$ 's power to revoke the trust took the form of a contingency which could not be valued, then presumably under Robinette $v$. Helvering ${ }^{130}$ nothing would be subtracted from the value of the trust property in determining the amount of $A$ 's gift.

Like most legal precepts, the rule that a contingent power to alter or revoke a transfer will not prevent a complete transfer and a taxable gift if the contingency upon which the power can be exercised is not within the control of the transferor may be easier to state abstractly than it is to apply in a specific situation. It is obvious that there are different degrees of control. Declaring that a transfer that can be altered or revoked upon the occurrence of a contingency is not a complete transfer and a taxable gift if the contingency is something within the transferor's control does not mean much unless there is some definition of what is meant by the transferor's control. Some contingencies are obviously within or without the transferor's control, but there is also a gray area where determining whether a contingency is within the transferor's control depends upon how control is defined. For example, if $A$ transfers property to $T$ in trust for $C$ and retains power to revoke the trust upon giving notice of thirty days to the trustee, giving notice is obviously a contingency within $A$ 's control, and the transfer is incomplete for gift tax purposes. At the opposite extreme, if $A$ retains power to revoke the trust if a Republican is elected Presi- 
dent of the United States, the contingency upon which the power to revoke may be exercised is obviously beyond the transferor's control; there is a complete transfer and a taxable gift. Suppose, however, that $A$ retains power to revoke the trust if he marries or gets divorced. Is the contingency upon which the exercise of the power hinges an event within or without $A$ 's control?

It is obvious that one thing which complicates the tax status of contingent powers is that the criteria which are used to determine whether a contingency negatives the existence of a power for tax purposes are utterly irrelevant. Taxes are imposed upon the existence of a power because of the control which the power gives the owner of the power over the income or property subject to the power. The income from a revocable trust is taxed to the grantor of the trust because, due to the power he has over the trust property, he has not parted with control over the property. ${ }^{131}$ For the same reason, the trust property will be taxed to his estate under the estate tax, and he will not be treated as having made a taxable gift for purposes of the gift tax. From the viewpoint of the policy underlying the taxation of powers, whether a contingency negatives the existence of a power for tax purposes should depend upon whether the contingency detracts from the control that the owner of the power has over the property subject to the power to an extent that makes it unfair to treat him as owner of the property subject to the power for tax purposes. It is obvious that a power is in no respect limited by a contingency within the control of a transferor and, therefore, the contingency may be disregarded for tax purposes.

Whether other contingencies limiting the exercise of powers should negative a power for tax purposes involves a careful analysis of the extent to which the contingency impedes the control that the owner of the power has over the property subject to the power and the degree of control which justifies sticking him with a tax liability. It is obvious, however, that this is a very uncomfortable approach, which would create great uncertainty and, unless it were backed up by legislation specifying the tax effects of various types of contingencies, would in many cases make tax liability turn upon the subjec-

\footnotetext{
${ }^{131}$ See Corliss v. Bowers, 281 U.S. 376 (1930), where Mr. Justice Holmes in up. holding the constitutionality of taxing the income from a revocable trust to the grantor of the trust said: "But taxation is not so much concerned with the refinements of title as it is with actual command over the property taxed-the actual benefit for which the tax is paid." Id. at 378.
} 
tive evaluation of the particular judge. Presumably, in order to escape from this type of inquiry, the courts have turned to verbal irrelevancies to determine the tax effects of contingent powers. Although it is not meaningful, it is easy to say that a contingent power does not "exist" for tax purposes until the contingency upon which the exercise of the power depends has occurred. Of course, the only reason that the power is not in existence as long as the contingency has not happened is that "exist" is defined to exclude contingent powers in order to settle the taxation of those powers. Actually, when one says that a contingent power does not exist for tax purposes, all that he is saying is that contingent powers are not taxable because contingent powers are not taxable. If one does not want to talk about "existence," because it seems obvious that a conditional power does exist just as an unconditional power exists, he can resort to the word "vest" which has esoteric legal connotations. It could be argued, if a statute is worded as section 166 of the 1939 Code was, ${ }^{132}$ that a contingent power to revoke a trust does not make income taxable to the grantor of the trust because the power is "contingent" and not "vested." Of course, the underlying assumption here is that Congress was made up of medieval conveyancers who used "vested" not in the popular sense of "owned," but in a highly technical sense, and who were alluding to the property distinction between vested and contingent interests. One diffculty with this approach is that it may prove embarrassing when there is an inadvertent change in the statutory language. Section 676 of the 1954 Code does not provide that a power to revoke a trust must be "vested" in the grantor of the trust to make the income from the trust taxable to the grantor of the trust. How would section 676 of the 1954 Code be handled? This, of course, brings one full circle to the ultimate question of how to treat contingent powers. If it is felt that a contingent power to revoke should not make income from a trust taxable to the grantor of the trust under section 676 of the 1954 Code, it is easy to achieve this result by glossing over the word "vested" and pointing out that contingent powers did not have this effect under section 166 of the 1939 Code, and when Congress adopted section 676 of the 1954 Code, it intended to re-enact section 166 and the judicial interpretation of that section. This is not designed as a criticism of the way in which

\footnotetext{
${ }^{232}$ See note 119 supra.
} 
courts have handled the tax effects of contingent powers. It is simply an attempt to analyze what they actually do. Courts are called upon to decide cases. They must determine what effect a contingency has on a power for tax purposes. It would be impractical to decide in each individual case whether the particular contingency prevented the owner of the power from exercising that degree of control upon which tax liability might justly be predicated. Since practical considerations preclude reliance upon relevant factors in passing upon the tax consequences of contingent powers, the courts have resorted to more or less irrelevant semantics, which are perhaps as satisfactory a way as any for deciding cases in this field. After all, construction of tax statutes is not an area where judicial decisions are irretrievable. If the courts make mistakes, Congress can correct them.

\section{Fiduciary Powers}

The exercise of a power may be limited by the inability of the owner of the power to exercise the power unless he is acting in a certain capacity. For example, $A$ may transfer property to himself and another in trust for $B$ for life, remainder to $C$ in fee, and give the trustees a power to invade the corpus of the trust in behalf of the income beneficiary. $A$ can only exercise this power in his capacity as a co-trustee.

Apart from several specific statutory exceptions, the fact that a power can only be exercised in a fiduciary capacity is unimportant under the federal income, estate, and gift taxes as long as the power is a discretionary power. Thus, in the hypothetical case, if the trustees had complete discretion about invading the corpus of the trust for $B$, the trust property would be taxable to $A$ 's estate under section 2038 of the estate tax..$^{133}$ If, on the other hand, the trustees could only invade corpus to the extent necessary for $B$ 's education and support, the power would not make the trust property taxable to $A$ 's estate. ${ }^{134}$ The taxation of the trust property under section

\footnotetext{
${ }^{183}$ E.g., Round v. Commissioner, 332 F.2d 590 (1st Cir. 1964); State Street Trust Co. v. United States, 263 F.2d 635 (1st Cir. 1959); Hurd v. Commissioner, 160 F.2d 610 (1st Cir. 1947); Estate of Cyrus C. Yawkey, 12 T.C. 1164 (1949); Estate of Albert E. Nettleton, 4 T.C. 987 (1945); Rev. Rul. 57-366, 1957-2 CuM. BuLL. 618. In a close case the decision as to whether a power is a discretionary power may be affected by the fact that it can be exercised only in a fiduciary capacity. See 32 Rocky MT. L. REv. 223 (1960).

${ }^{184}$ E.g., Estate of Robert W. Wier, 17 T.C. 409 (1951); Estate of C. Dudley Wilson, 13 T.C. 869 (1949), aff'd per curiam, 187 F.2d 145 (3d Cir. 1951).
} 
2038 of the estate tax in the case of the discretionary power is peculiarly pertinent because section 2038, or rather its predecessor under the pre-existing law, was amended in 1936 to expressly tax powers "in whatever capacity exercisable."135 Although the form of the statute limits the amendment to transfers made after the enactment of the $1936 \mathrm{Act}$, it has been applied to transfers made before the statute was amended, on the theory that it simply made articulate the pre-existing law. ${ }^{136}$

There are several situations where by virtue of some specific statutory provision the fact that a power can be exercised only in a fiduciary capacity has tax consequences. Thus, for example, section 674 (c) provides that a power to sprinkle the income or corpus of a trust among the beneficiaries of a trust will not make the income from the trust taxable to the grantor if it is vested in independent trustees. Section 674 (d) provides that power to allocate income among the beneficiaries of a trust according to an external standard will not make the income from the trust taxable to the grantor of the trust, if the power is held by a trustee or trustees other than the grantor of the trust or a spouse of the grantor living with the grantor. According to section $677(\mathrm{~b})$, the existence of a power to apply income from a trust to the support of a dependent of the grantor, whom the grantor is legally obligated to support, will not make the income from the trust taxable to the grantor, if it can be exercised only by a trustee of the trust or the grantor acting as a trustee. Finally, section 678 (c) provides that the existence of a power to apply income from a trust to the support of a dependent, whom the person holding the power is legally obligated to support, will not make the income from the trust taxable to the person possessing the power, if he can exercise the power only in the capacity of a trustee or co-trustee.

\section{CONCLUSION}

What are the tax consequences of limitations upon the exercise of powers? Apparently extrinsic limitations have no tax conse-

${ }^{285}$ Revenue Act of 1936, ch. 690, $\$ 805,49$ Stat. 1744.

${ }^{180}$ Treas. Reg. $\S 20.2038-1$ (c) (1958). In Commissioner v. Estate of Holmes, 326 U.S. 480,489 n.13, 490 (1946), the Supreme Court left this question open. The lower courts, however, sustain the position taken by the regulations. E.g., Jennings v. Smith, 161 F.2d 74, 77 (2d Cir. 1947); Hurd v. Commissioner, 160 F.2d 610, 613 (Ist Cir. 1947); Commissioner v. Newbold's Estate, I58 F.2d 694, 695 (2d Cir. 1946); Welch v. Terhune, 126 F.2d 695, 698 (Ist Cir.), cert. denied, 317 U.S. 644 (1942). 
quences. Neither the impossibility of exercising a power, nor lack of legal capacity to exercise a power, will negative the existence of the power for tax purposes.

The tax effects of intrinsic limitations on the exercise of powers are more complex. They depend upon the particular tax and the particular type of limitation involved in the specific situation.

The requirement that another person must join in the exercise of a power, or that one other than the creator of a power may exercise the power, is treated differently under the income, estate, and gift taxes. With the exception of powers of appointment, the estate tax treats a power exercisable by a decedent alone and the decedent in conjunction with any other person, including an adverse party, in the same way. On the other hand, powers exercisable without the decedent's participation are not taxed under the estate tax.

The income tax takes a different approach. Income from a revocable trust is taxable to the grantor of the trust as long as power to alter or revoke the trust can be exercised without the concurrence of an adverse party, regardless of whether or not the grantor must participate in the exercise of the power.

The gift tax, which is the only one of the three taxes that lacks an explicit definition of a revocable transfer, comes at revocable trusts from a still different angle. Under the gift tax, the test of a complete transfer and a taxable gift is whether the transferred property has passed beyond the transferor's control. The gift tax assumes that this has occurred when a transfer cannot be altered or revoked without the consent of a person possessing a substantial adverse interest in the transferred property. Since transfers which can be altered or revoked by one other than the transferor are treated as complete transfers that escape the estate tax, they should be taxed under the gift tax. The law on this point is, however, uncertain.

It is difficult to see any reason why revocable transfers should be defined differently under the income, estate, and gift taxes. The same measure of control that justifies taxing the income from transferred property to the transferor should be sufficient to keep the property in his estate for purposes of the estate tax and to prevent the imposition of the gift tax. The income tax properly treats trusts as revocable regardless of whether the grantor must participate in the exercise of a power to alter or revoke the trust. From the view- 
point of actual control, there is no difference between a trust revocable by the grantor alone, a trust revocable by the grantor with the concurrence of the trustee or revocable by the trustee with the concurrence of the grantor, and a trust revocable by the trustee alone. The trusts are treated as identical for the purpose of taxing the income from the trust to the grantor of the trust under the income tax. They should be treated as identical under the estate tax.

The distinction drawn by the income tax between adverse and nonadverse parties has a superficial plausibility that disappears on closer analysis. In view of the fact that the courts have generally defined an adverse party as a person possessing a substantial beneficial interest in transferred property, regardless of the fact that he may have been selected by the transferor to participate in the exercise of a power because he is actually subservient to the transferor, the requirement that an adverse party must participate in the exercise of a power to alter or revoke a transfer is no guaranty that the transferred property has passed beyond the control of the transferor. The income tax would do well to follow the estate tax with regard to adverse persons and disregard any distinction between adverse and nonadverse parties entirely.

Regardless of the reality of the income tax distinction between adverse and nonadverse parties, it is obvious that the statutory provisions for independent trustees and related or subordinate parties subservient to the grantor are meretricious window dressing that constitute a tax trap for the unsophisticated draftsman without any compensating advantage for the federal fisc. Since the statute actually permits vesting a power to sprinkle the income or corpus of a trust among the beneficiaries of the trust in trustees who are not independent, without making the income from the trust taxable to the grantor, why pretend otherwise?

Both the income tax and the estate tax seem to be partly right and partly wrong in their definitions of revocable transfers. The income tax is correct in refusing to limit revocable transfers to trusts whose grantor must participate in the exercise of a power to alter or revoke the trust. The estate tax is correct in treating transfers as revocable even though a power to revoke the transfer is dependent upon the concurrence of a person possessing a substantial adverse interest in the transferred property. It would seem that 
the proper way to define a revocable transfer under the income and estate taxes would be to combine the correct elements of the current definitions of revocable transfers under both taxes and to say that a transfer that can be revoked by anyone, other than all of the persons beneficially interested in the transferred property, is a revocable transfer.

With the uniform definition of revocable transfers under the income and estate taxes, the definition of an incomplete transfer under the gift tax would be axiomatic. Since the sole purpose of the gift tax is to supplement the income and estate taxes, a transfer would be incomplete (nontaxable) under the gift tax as long as the transfer was treated as a revocable transfer under the income and estate taxes. That is, a transfer would be incomplete under the gift tax as long as it could be revoked by anyone other than all of those persons beneficially interested in the transferred property.

A person who holds a power over property is treated as the owner of the property for tax purposes because the power gives him the control of an owner. It follows that the tax effects of a contingent power should be judged by the extent of the impediment which the contingency interposes to the exercise of the power. Does the contingency dilute the powerholder's control over the property subject to the power to such an extent that it is no longer equitable to treat him as owner of the property for tax purposes?

It is obvious that a contingency limiting the exercise of a power does not really limit the exercise of the power, if the contingency is something within the control of the owner of the power, such as giving notice of an intention to exercise the power. The courts recognize this in holding that contingencies within the control of the powerholder do not affect the power for tax purposes. In the case of real contingencies, however, the courts have been reluctant to consider the effect of a contingency upon the ability to exercise a power. It was generally held under the 1939 Code that a contingency negatived the existence of a power for tax purposes because a contingent power was not "vested" as the income tax provision dealing with revocable trusts required, or was not in "existence" at the powerholder's death for purposes of the estate tax. It would be possible to distinguish some of the cases decided under the pre-existing law on the basis of differences in language under the 1954 Code, although it appears unlikely that the courts 
will do so. The decisions under the prior law were predicated upon verbal irrelevancies to avoid the painful process of evaluating the impediment which a particular contingency interposed to the exercise of a particular power and its effect on the powerholder's control over the property subject to the power. One underrates the ingenuity of the courts if he thinks they will not be able to find verbal irrelevancies to negative the existence of contingent powers for tax purposes under the 1954 Code.

Deciding the tax effects of a contingent power by considering the extent to which the contingency limits the powerholder's control over the property subject to the power involves several difficult determinations. First of all, it is necessary to appraise the extent to which the contingency actually interferes with the powerholder's control over the property subject to the power. Then it is necessary to make a value judgment as to what degree of interference with the powerholder's control justifies disregarding a contingent power for tax purposes. It might be possible to develop a doctrine that would disregard contingent powers for tax purposes only when the contingency limiting the exercise of the power was a remote contingency which was extremely unlikely to happen. Any such doctrine would, of course, require drawing the line between probable and improbable contingencies and thrust the courts into an area where the final determinant in many cases would be a subjective judicial judgment as to where that line should be drawn.

In the absence of an explicit statutory provision, the fact that a power can only be exercised in a particular capacity has no effect upon the existence of the power for tax purposes. For example, if $A$ declared himself trustee of securities for $B$ and gave the trustee of the trust unlimited power to alter or revoke the trust, the fact that $A$ could only exercise this power in his capacity as trustee would not prevent the income from the trust being taxed to him under the income tax. Nor would it prevent inclusion of the trust property in $A$ 's estate under the estate tax; nor make creation of the trust a taxable transfer under the gift tax. In other words, the tax consequence of the power would be just the same as though $A$ had retained power to alter or revoke the trust in his individual capacity as grantor.

Although the courts have found no perceptible tax differences between discretionary powers which can be exercised in an indi- 
vidual capacity and those which can be exercised only in a fiduciary capacity, the statute occasionally draws a distinction. Sections 674 (b) (1) and 677 (b) provide that the existence of a power in the grantor of a trust to use income from the trust to support a dependent whom he is legally obligated to support, will not make the income from the trust taxable to the grantor of the trust as long as he can exercise the power only in a fiduciary capacity. Section 678 (c) contains a similar exception in connection with a power to use income from a trust to support a dependent of one other than the grantor of a trust. The existence of a power to use income from the trust to support a dependent of the powerholder will not make the income from the trust taxable to the powerholder, if he can exercise the power only as a trustee or co-trustee of the trust. There are good reasons for providing that the mere existence of a power to apply income for the support of a dependent of the powerholder should not make the income available for that purpose taxable to the possessor of the power. It seems doubtful, however, whether limiting this exception to situations where the power can be exercised only in a fiduciary capacity does more than complicate the law, since the prescribed limitation is not a real limitation on the powerholder's ability to exercise the power. 